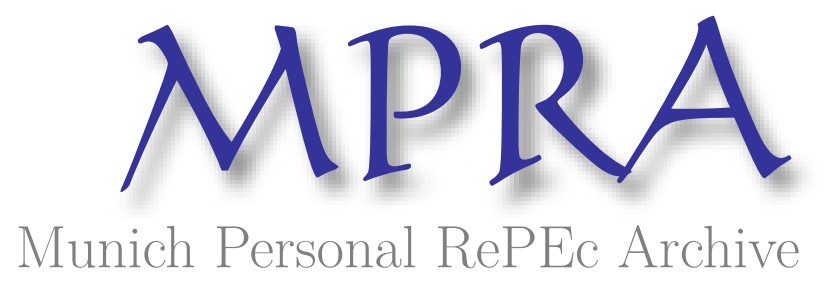

\title{
Sovereign defaults, external debt and real exchange rate dynamics
}

\author{
Asonuma, Tamon \\ International Monetary Fund
}

23 March 2014

Online at https://mpra.ub.uni-muenchen.de/55133/

MPRA Paper No. 55133, posted 09 Apr 2014 19:59 UTC 


\title{
Sovereign Defaults, External Debt and Real Exchange Rate Dynamics*
}

\author{
Tamon Asonuma ${ }^{\dagger}$
}

March 23, 2014

\begin{abstract}
Emerging countries experience real exchange rate depreciations around defaults. In this paper, we examine this observed pattern empirically and through the lens of a dynamic stochastic general equilibrium model. The theoretical model explicitly incorporates bond issuances in local and foreign currencies, and endogenous determination of real exchange rate and default risk. Our quantitative analysis, using the case of Argentina's default in 2001, replicates the link between real exchange rate depreciation and default probability around defaults and moments of the real exchange rate that match the data. Prior to default, interactions of real exchange rate depreciation, originated from a sequence of low tradable goods shocks with the sovereign's large share of foreign currency debt, trigger defaults. In post-default periods, the resulting output costs and loss of market access due to default lead to further real exchange rate depreciation.
\end{abstract}

JEL Classification Codes: E43; F32; F34; G12

Key words: Sovereign defaults; External debt; Real exchange rate; Currency composition of debt;

${ }^{*}$ The views expressed in this paper are those of the author and do not reflect any views of the International Monetary Fund. I thank Manuel Amador, Marianne Baxter, Nicola Borri, Matthieu Bussiere, Marcos Chamon, Bora C. Durdu, Douglas Gale, Francois Gourio, Simon Gilchrist, Juan C. Hatchondo, Laurence Kotlikoff, Alberto Martin, Leonardo Martinez, Akito Matsumoto, Kris Mitchener, Ugo Panizza, Romain Ranciere, Francisco Roch, Martin Schneider, Christian Siegel, Cedric Tille, Christoph Trebesch, Adrien Verdelhan, and Mark Wright, as well as seminar participants at Bank of Japan, Birmingham Business School, Boston University, Exeter Business School, Halle Institute for Economic Research, IMF AFR, IMF ICD, IMF RES, Keio Univ, Osaka Univ, and University of Munich for comments and suggestions. Additional thanks go to Haitham Jendoubi for research assistance and Christina M. Gebel for proof reading. All remaining errors are my own.

${ }^{\dagger}$ International Monetary Fund, 700 19th Street, N.W. Washington, D.C. 20431 USA. tasonuma@imf.org 


\section{Introduction}

Emerging market economies experience real exchange rate depreciations around the default events. We first empirically examine this stylized fact. The theoretical part of the paper explores interactions between real exchange rate and default decision in a stochastic general equilibrium model featuring defaultable debt. Our quantitative analysis, using Argentina's default episode in 2001, successfully explains the link between real exchange rate depreciation and default probability and also matches the relevant moments in the data.

In the empirical section, we present a new stylized fact on real exchange rate dynamics around sovereign defaults. For 18 sovereign debt default and restructuring episodes in 1998-2013, we find the empirical link between the real exchange rate depreciation and default risk (default decision): In the period prior default, the real exchange rate depreciation increases the burden of payments and ultimately triggers the default. In the post-default period, the country's announcement of default, or restructuring, leads to further real exchange rate depreciation. Our results on cross-sectional analysis, using these episodes, also confirm the observed link - a new contribution to the literature on sovereign defaults. Motivated by this stylized fact, we aim to answer the following two questions which are not explained in the literature: What drives real exchange rate depreciation leading to the country's default decision in the pre-default period? What leads to further real exchange rate depreciation in the post-default period?

The theoretical part of this paper attempts to explore interactions between real exchange rate and default decision in a standard dynamic model of defaultable debt, where a sovereign debtor borrows from a foreign creditor through bond issuances in local and foreign currencies. Both the country and the representative creditor are risk-averse and subject to tradable and non-tradable goods shocks. The real exchange rate, defined as relative consumer price indices (CPI) between the sovereign and the creditor, interacts with the prices of two debt instruments issued by the sovereign - incorporating default risk which increases with level of debt. Prior to default, the sovereign, receiving a sequence of low income shocks in tradable sector, tends to accumulate more debt and is more exposed to real exchange rate depreciation due to increased default risk. Since a majority of debt is denominated

in foreign currency as observed in data, the real exchange rate depreciation increases the burden of payments in terms of local currency, increasing default probability and ultimately proceeding to the 
default decision of the sovereign.

Once the sovereign declares default, it suffers output costs associated with default and loses access to the markets. By achieving financial autarky, the sovereign opts to have higher consumption of traded goods, indicating lower marginal utility of consumption, which leads to higher prices of nontraded goods and a higher overall price level relative to that of foreign creditors. Thus, it results in a further depreciation of the real exchange rate. This mechanism drives the equilibrium depreciation of the real exchange rate around defaults, and it is a plausible explanation of the observed patterns in the data.

The model is calibrated to the case of Argentina's default in 2001. Our quantitative exercise successfully replicates both business cycle and non-business-cycle moments that match with the data. Most importantly, our model generates real exchange rate moments consistent with what we observe in the Argentine data, particularly a higher average real exchange rate in the post-default periods than in the pre-default periods. The current model explains the observed real exchange rate dynamics around defaults.

We embed the real exchange rate dynamics and currency denomination of debt in a dynamic, sovereign debt model with endogenous default. This part of the model builds on the recent quantitative analysis of sovereign debt such as Aguiar and Gopinath (2006), Arellano (2008), and Tomz and Wright (2007), all of which are based on the classical setup of Eaton and Gersovitz (1981). To account for the creditor's willingness to avoid real exchange rate risks and demanding an excess risk premium as observed in the real world, we depart from the conventional risk-neutral investor assumption. Instead, we assume a "representative" risk-averse creditor who faces exogenous income shocks, as in Borri and Verdelhan (2009) and Lizarazo (2013). Our model also amends the tranditional debt issuance in domestic currency and considers that a sovereign issues external bonds in both local and foreign currencies, as observed in the data, extending a traditional assumption of domestic currency debt issuance.

The rest of the paper is structured as follows. Following the literature review, Section 2 overviews stylized facts and empirical analysis on real exchange rate dynamics and sovereign defaults. We provide our dynamic stochastic general equilibrium model in Section 3. Recursive equilibrium of the model is defined in Section 4. Quantitative analysis of the model is shown in Section 5. Section 6 discusses model implications. A short conclusion summarizes the discussion. A computation algorithm 
is presented in Appendix A.

\section{$1.1 \quad$ Literature Review}

Our paper builds on some strands of existing literature. First, this paper is related to the literature of sovereign debt and defaults, which extends a classical model of Eaton and Gersovitz (1981) and applies quantitative analysis. Arellano (2008) and Aguiar and Gopinath (2006) explore the connection between endogenous default, interest rates and income fluctuations in a model of sovereign debt and generate empirical regularities in emerging markets. Arellano and Heathcote (2010) explore what determines credit limits and how these vary across exchange rate regimes in a sovereign debt model. ${ }^{1}$ Asonuma (2012), Benjamin and Wright (2009), Bi (2008), and Yue (2010) model debt renegotiation after defaults and explain observed evidence of debt restructurings. This paper differs in that we mainly focus on interactions between default choices and real exchange rate dynamics.

The second grouping of literature deals with sovereign debt and risk-averse investors. Borri and Verdelhan (2009), Lizarazo (2013), and Presno and Puozo (2011) study the case of risk-averse lenders and show that risk aversion allows the model to generate spreads larger than default probabilities, as observed in emerging markets. Borri and Verdelhan (2009) consider risk aversion with external habit preference, whereas Lizarazo (2013) assumes decreasing absolute risk aversion (DARA). On the contrary, Presno and Puozo (2011) introduce fears about model misspecification for the lenders. What distinguishes this current paper with these studies is that we incorporate real exchange rate determination together with bond prices.

Lastly, this paper also contributes to the literature on currency compositions of external debt. Jeanne (2003) claims that unpredictable monetary policy increasing the uncertainty in the future real value of domestic currency debt may induce sovereigns to dollarize their liabilities. Bussiere, Fratzcher and Koeniger (2004) link the exchange rate uncertainty in foreign currency debt to solvency of debt and the choice of debt maturity, and Chamon and Hausmann (2004) explore theinterplay between an individual borrower's choices for liability denomination through the effect on optimal monetary response of the central bank. On the contrary, Eichengreen, Hausmann and Panizza (2004) consider that an inability to borrow abroad in domestic currency ("original sin") is owing to structure and

\footnotetext{
${ }^{1}$ Jahjah et al. (2012) empirically analyze how exchange rate policy affects the supply and pricing of sovereign bonds in developing countries.
} 
operation of the international financial system together with weakness of policies and institutions. ${ }^{234}$ This paper complements existing studies by explaining how behavior of foreign creditors, avoiding the real exchange rate risk, leads to lending in foreign currency rather than local currency. ${ }^{5}$

\section{Stylized Facts and Empirical Analysis}

In this section, we provide an observed evidence and empirical analysis on real exchange rate dynamics and sovereign defaults. From recent sovereign default and restructuring episodes, there exists an empirical link between real exchange rate depreciation and a sovereign's default choices. Our results on cross-sectional analysis also support the observed link.

\subsection{Real Exchange Rate Dynamics around Defaults/Restructurings}

Figure 1 displays fluctuations of real exchange rates against the US dollar in quarterly frequency before and after defaults/announcements of restructurings from 18 episodes in 1998-2013. ${ }^{6}$ Following definitions of preemptive and post-default restructurings in Asonuma and Trebesch (2013), we set $t$ at time of defaults for post-default restructuring cases and at time of announcements of restructurings for preemptive episodes. ${ }^{78}$ Real exchange rates are normalized with respect to levels at the time of

\footnotetext{
${ }^{2}$ Burger and Warnock (2006) stress that by improving policy performance and strengthening institutions, emerging economies may develop the local currency bond market, reduce their currency mismatch and lessen the likelihood of future crises.

${ }^{3}$ Aghion, Bacchetta, and Banerjee (2004) propose the following: borrowers can use unsecured debt in domestic currency as collateral to obtain a loan in foreign currency. This reduces the interest rate on foreign currency debt since, in the case of a crisis, the loss is partially transferred to lenders in domestic currency.

${ }^{4}$ In addition, Corsetti and Mackowiak (2004) show how monetary and fiscal policies, including maturity and currency denomination of debt, interact to determine the dynamic response of the economy and magnitude of devaluation and inflation.

${ }^{5}$ We relate our paper to the literature on portfolio allocation between an emerging market economy and an advanced economy as in Devereux and Sutherland (2009) and Tille and Van Wincoop (2010), which examine determinants of optimal risk-sharing allocations. Coeurdacier and Gourinchas (2013) consider international portfolio with real exchange rate and non-financial risks that account for observed levels of equity home bias.

${ }^{6}$ We exclude episodes of default/debt restructurings of external debt held by official creditors because of the absence of precise data on defaults and announcements of restructurings. Moreover, for default/restructuring of external debt held by private creditors, cases of Antigua and Barduba, Serbia and Montenegro, and Iraq are not included due to a lack of quarterly data on both nominal exchange rates and CPI. The case of Greece is not included in our sample due to the absence of nominal exchange rate against the euro associated with Eurozone membership.

${ }^{7}$ Asonuma and Trebesch (2013) introduce a new typology of two types of sovereign debt restructurings: those implemented prior to a unilateral payment default, which they term "preemptive," and those where the government defaults first and then starts to renegotiate its debt later on, which are termed as "post-default" cases.

${ }^{8}$ An alternative approach is to use selective default (SD) ratings on foreign currency debt by Standard and Poor's. We have a smaller sample of 12 default/restructuring episodes than our original sample of 18 episodes. This sample also excludes episodes of defaults/restructurings of debt held by official creditors. As expected, with the smaller sample, we also replicate similar real exchange rate dynamics before/after downgrading to selective default ratings.
} 
defaults or announcements of restructurings. We observe an empirical link between the real exchange rate depreciation and default risk (default choice): on one hand, the real exchange rate depreciation increases a burden of payments for a sovereign country and triggers a default; on the other hand, the country's announcement of default or restructuring leads to further real exchange rate depreciation. Exceptions are Ecuador in 2008 for the pre-default period and the Dominican Republic and Ukraine 2000 for the post-default period. ${ }^{91011}$

Figure 1: Real Exchange Rates Against the US Dollar Before and After Defaults/Restructurings

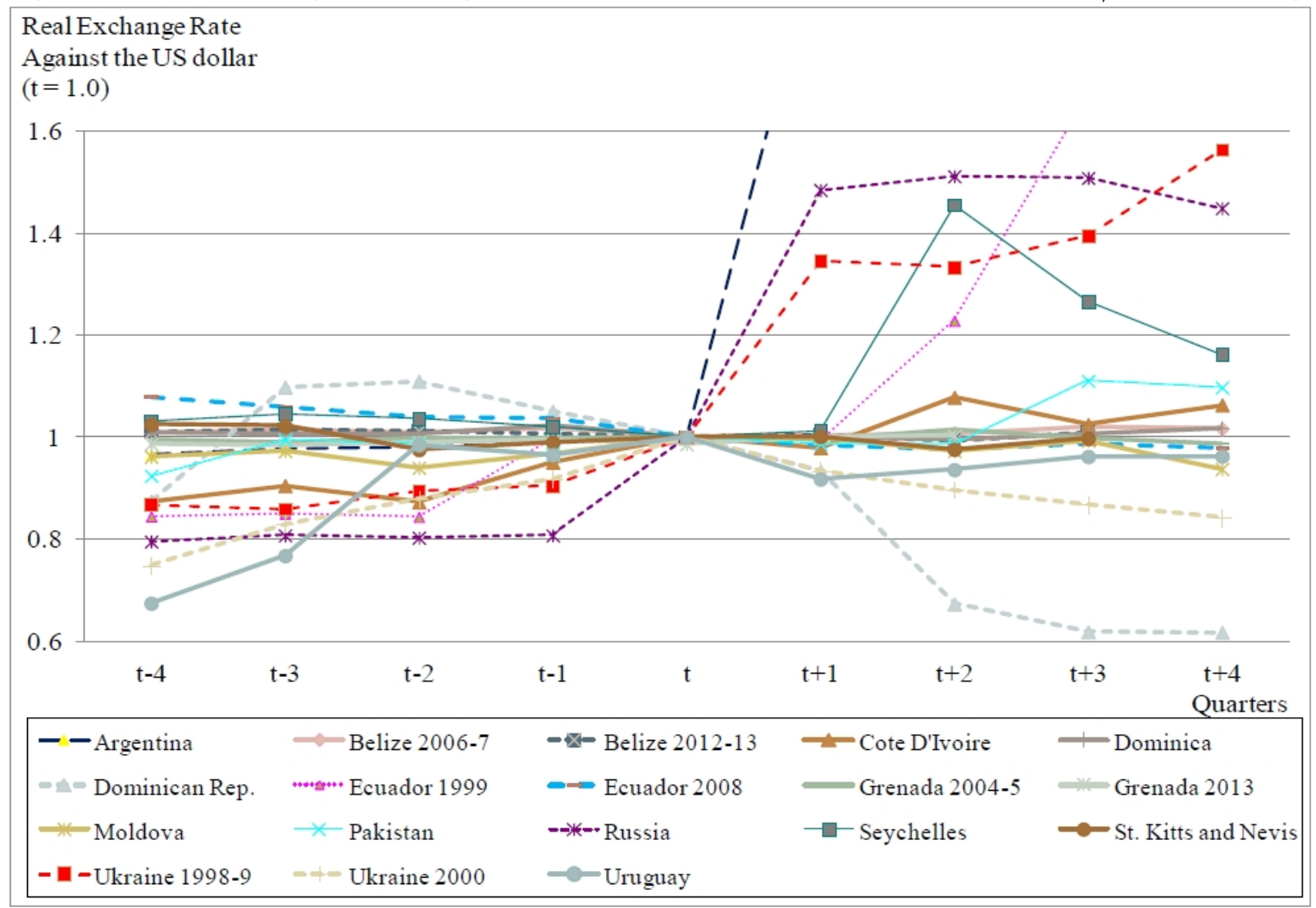

\footnotetext{
${ }^{9}$ The Ecuador 2008 episode can be treated as exceptional since it announced in December 2008 that the government missed an interest payment of $\$ 30.6$ million on its $\$ 510$ million of $12 \%$ global bonds due in 2012 . Prior to the announcement, the authorities made statements in November 2008 that the 2012 and the 2030 securities were "illegal" and "illegitimate." Therefore, default was considered to be triggered by political decision rather than solvency or liquidity concerns.

${ }^{10}$ The Dominican Republic in 2004-5 is also considered an outlier since it announced its debt restructuring on private debt in April 2004, following restructuring on official sector debt. However, its debt restructuring had proceeded in two separate approaches. For bank loans, though the sovereign started its negotiation with creditors in August 2004, it missed its payments in February 2005 and launched the final exchange offer in June 2005, which was completed later in October 2005. On the contrary, for external bonds, after negotiation was initiated in January 2005, the sovereign launched the final exchange offer in April 2005 and completed the exchange later in May 2005.

${ }^{11}$ In the case of Ukraine 2000, the real exchange rate had been on a depreciation trend for 9 quarters until its peak in January 2000 (depreciated by 95 percent compared to the level in November 1997) due to the first default/restructuring in 1998-9. Therefore, in the post-default period, we observed a slight rebound of the real exchange rate (appreciated by 15 percent compared to the level in January 2000).
} 
Source: Asonuma and Trebesch (2013), IMF IFS

\subsection{Empirical Analysis of the Link}

With our sample of 18 episodes, empirical analysis attempts to examine a relationship between real exchange rate depreciations and default probability (default choice) in both pre-default and postdefault periods. ${ }^{12}$ First, in pre-default periods, we explore whether the level of lagged real exchange rates leads to an increase in default probability. Our sample is in quarterly frequency, and each episode covers periods from 5 quarters before to time of defaults/announcement of restructurings. For a proxy for default probability, we use credit ratings on foreign currency debt, which are transformed into discrete forms following Sy (2002). ${ }^{1314}$ One advantage of this approach is to capture the high degree of variation in default probability. Since lagged real exchange rates are normalized, with respect to their level at defaults/announcement of restructurings, these series reflect the magnitude of depreciations towards the levels at default/announcement of restructurings. ${ }^{15}$ Given the possibility of an endogeneity problem, we apply a two-step generalized method of moment (GMM) estimation using both US GDP deviation from the trend and the US Treasury bill rate as instruments for lagged real exchange rates. These instruments have enough explanatory power, as shown in high $A d j-R^{2}$ reported in Table A1 in Appendix 2. Our specification is the following:

$$
\operatorname{Rating}_{t}=E R_{t-1} \beta+Z_{t-1} \gamma+Z_{t} \gamma^{\prime}+\varepsilon_{1, t}
$$

where $E R_{t-1}$ are estimates of lagged real exchange rates, $Z_{t-1}$ and $Z_{t}$ are vectors of other explanatory variables at time $t-1$ and $t$, respectively. Our choice of control variables has been guided by the literature on sovereign debt crises and is especially close to Kohlscheen (2009) and Dreher and Walter (2010). We include GDP growth rates, debt service-to-GDP, an indicator of institutional quality, and 1-year LIBOR rates in baseline specification, which are found to be key factors in the sovereign debt crisis literature. An indicator of the IMF program is also added to the list since whether or not an

\footnotetext{
${ }^{12}$ Details and sources of variables used in empirical analysis are reported in Appendix B.

${ }^{13}$ The alternative approach is to use a binary variable showing default and non-default choices and to apply a probit estimation. This method also provides results similar to Table 1, with a smaller degree of significance. Our approach enables us to receive benefits of better fits derived by sovereign risk ratings, which capture the high degree of variation in default probability.

${ }^{14}$ Sy (2002) convert S\&P's and Moody's ratings to numerical values using a linear scale from 0 to 20 with S.D. and $\mathrm{CC} / \mathrm{Ca}$ ratings corresponding to values of 0 and 1, respectively, and AAA/Aaa ratings being assigned a value of 20.

${ }^{15}$ We also regress with changes in real exchange rates and obtain results with less significance.
} 
IMF-supported program is put in place affects defaults or restructurings.

Baseline pooled regression results (2nd column) confirm that the real exchange rate depreciation (lagged) increases default probability: depreciations, expressed by higher levels of real exchange rates entered with lagged, lead to lower levels of ratings implying higher default probability/default choice. In line with empirical findings in the sovereign debt crisis literature, default probability is high if GDP growth is low and debt burden (debt service-to-GDP) is high. This is consistent with findings in theoretical literature of sovereign debt and defaults using one-period bonds. Moreover, when an indicator of institutional quality is low and a sovereign does not have an IMF-supported program, the sovereign is more likely to default. The results are robust if we attempt to reflect heterogeneity in sovereign risk ratings by applying fixed effect regression (3rd column). All relevant variables, except an indicator of the IMF program, remain in expected signs with significance.

Table 1: Regression Results for the Pre-Default Period

\begin{tabular}{lll}
\hline \hline Dependent variable: Ratings & $(\mathrm{A})$ Baseline. & $(\mathrm{B})$ Fixed effect \\
\hline \hline Estimation & 2-step GMM Pooled & 2-step GMM Fixed-effect \\
\hline Real Exchange rate, lagged & $-14.34^{* * *}(2.49)$ & $-8.17^{* * *}(2.89)$ \\
\hline GDP growth rate, lagged & $0.17^{* * *}(0.06)$ & $0.08^{* *}(0.04)$ \\
\hline Debt service-to-GDP, lagged & $-0.09^{* * *}(0.02)$ & $-0.15^{* * *}(0.03)$ \\
\hline Institutional quality*1 & $0.31^{* * *}(0.04)$ & $0.15^{* * *}(0.04)$ \\
\hline IMF program & $1.24^{* * *}(0.40)$ & $-0.28(0.09)$ \\
\hline LIBOR 1-year & $-0.09(0.14)$ & $0.59^{* * *}(0.15)$ \\
\hline \hline Samples & 48 & 48 \\
\hline Root MSE & 1.23 & 0.60 \\
\hline \hline Note: ${ }^{* * *},{ }^{* * *}$ denote significant at $10 \%, 5 \%$, and $1 \%$, respectively.
\end{tabular}

${ }^{* 1}$ Institutional quality is the quarterly average of monthly PRC composite risk ratings from 1985-2012, with 100 and 0 as the highest and lowest indices, respectively.

Next, for the post-default period, we analyze whether default choices of sovereigns influence real exchange rate depreciation in subsequent periods. Our sample is in quarterly frequency, and each episode covers periods from time of defaults or announcements of restructurings to 5 quarters after. 
Ratings on sovereign bonds are treated as indicators of default choices. ${ }^{16}$ The same method of a two-step GMM regression is taken using credit ratings of other emerging countries in other regions with a similar size and degree of openness and quality of institution as instruments for lagged default probability. High $A d j-R^{2}$ in Table A2 in Appendix B confirms high explanatory power of these instruments. We apply the following specification:

$$
E R_{t}=\text { Rating }_{t-1} \beta+Z_{t} \gamma+Z_{t-1} \gamma^{\prime}+\varepsilon_{2, t}
$$

where Rating $_{t-1}$ are estimates of lagged ratings, $Z_{t-1}$ and $Z_{t}$ are vectors of other explanatory variables at time $t-1$ and $t$, respectively. For choice of control variables, we follow the literature on determinants of real exchange rates, especially Maeso-Fernandez et al. (2001) and IMF (2006). The set of explanatory variables in baseline specification includes GDP growth rate differential, real interest rate differential, net foreign assets-to-GDP and real oil price shock, which are considered to be dominant determinants of real exchange rates in the literature. In addition to these variables, we also include an indicator of an IMF program and 1-year LIBOR rates because real exchange rates are also influenced by the conditionality under an IMF program and global liquidity.

From baseline pooled regression results, we see that sovereigns' default choices, expressed as lower credit ratings, induce real exchange rate depreciations: defaults denoted by lower levels of ratings, entered with lagged, lead to real exchange rate depreciation shown by a higher level of subsequent real exchange rates. Similar to what the literature on determinants of real exchange rates has explained, real exchange rates depreciate when GDP growth rates and real interest rates are lower than those of partner countries and the sovereign reduces net foreign assets. An increase in real oil prices, considered as terms of trade shock, leads to depreciation in real exchange rates since deterioration of the terms of trade of a country should result in a real exchange rate depreciation of that country. On the contrary, neither the IMF program nor LIBOR rates have significant influence over real exchange rates. Obtained results are robust, even if we apply the pooled regression with global liquidity proxied by LIBOR rates and fixed effect regression.

\footnotetext{
${ }^{16}$ Using a binary variable showing default and non-default choices as one of the explanatory variables is an alternative approach. We obtain similar results shown in Table 2 with less significance.
} 
Table 2: Regression results for the Post-Default Period

\begin{tabular}{llll}
\hline \hline Dependent variable: Real Exchange Rates & (A) Baseline. & (B) w. Global liquidity & (C) Fixed effect \\
\hline \hline Estimation & 2-step GMM & 2-step GMM & 2-step GMM \\
\hline \multicolumn{1}{c}{ Pooled / Fixed-effect } & Pooled & Pooled & Fixed-effect \\
\hline Ratings, lagged & $-0.25^{* * *}(0.03)$ & $-0.26^{* * *}(0.03)$ & $-0.11^{* * *}(0.04)$ \\
\hline GDP growth differential, lagged & $-0.02^{* *}(0.009)$ & $-0.02^{* *}(0.01)$ & $-0.017^{* *}(0.009)$ \\
\hline Real interest rate differential, lagged & $-0.004^{* * *}(0.002)$ & $-0.004^{* *}(0.002)$ & $-0.009^{* *}(0.002)$ \\
\hline Net foreign assets-to-GDP, lagged & $-0.05^{* * *}(0.013)$ & $-0.05^{* * *}(0.014)$ & $-0.053^{* * *}(0.02)$ \\
\hline Real oil price shock dummy, lagged*1 & $2.67(1.62)$ & $3.04^{*}(1.57)$ & $1.55^{*}(0.90)$ \\
\hline IMF program & $1.36(1.10)$ & $1.53(1.07)$ & $0.49(0.67)$ \\
\hline LIBOR 1-year & - & $0.07(0.05)$ & $0.13^{*}(0.07)$ \\
\hline Constant & $0.72(1.06)$ & $0.43(1.02)$ & $0.77(0.55)$ \\
\hline \hline Samples & 32 & 32 & 32 \\
\hline Root MSE & 0.30 & 0.30 & 0.18 \\
\hline \hline
\end{tabular}

Note: ${ }^{*},{ }^{* *},{ }^{* * *}$ denote significant at $10 \%, 5 \%$, and $1 \%$, respectively.

${ }^{* 1}$ Real oil price shock is an indicator showing the world oil price index deflated by the US Producer Price Index (PPI) for countries heavily dependent on oil prices, while 0 is given for those less dependent on oil prices.

\section{Model Environment}

\subsection{General Points}

The basic structure of the model is in line with previous work, extending the sovereign debt model of Eaton and Gersovitz (1981). ${ }^{17}$ Our model embeds real exchange rate dynamics and currency denomination in a two-country framework. We consider a risk-averse sovereign and a representative risk-averse creditor. Their preferences are shown by following utility functions:

$$
E_{0} \sum_{t=0}^{\infty} \beta^{t} u\left(c_{t}\right), \quad E_{0} \sum_{t=0}^{\infty}\left(\beta^{*}\right)^{t} u\left(c_{t}^{*}\right)
$$

\footnotetext{
${ }^{17}$ Our incomplete market assumption of capital market under the two-country framework follows Benigno and Thoenissen (2008) and Chari, Kehoe and McGrattan (2002).
} 
where $0<\beta<1$ is a discount factor of the sovereign, and $0<\beta^{*}<1$ is a discount factor of the creditor. $c_{t}$ and $c_{t}^{*}$ denote consumptions of borrower and lender in period $t$, and $u($.$) is one-period$ utility function, which is continuous, strictly increasing and strictly concave, and satisfies the Inada conditions. A discount factor of the sovereign reflects both pure time preference and probability that the current sovereignty will survive into next period, whereas a discount factor of the creditor shows only pure time preference. An assumption of a risk-averse creditor is in line with the behavior of investors in emerging financial markets, who prefer to avoid real exchange rate risks. ${ }^{18}$

All information on income processes of two parties and bond issuances is perfect and symmetric. In each period, the sovereign starts with total debt $b_{t}$, a fraction dominated in local currency $\alpha b_{t}$, and the remaining denominated in foreign currency $(1-\alpha) b_{t}$. We provide a brief explanation of fixed share of foreign currency debt in Section 3.3.

Both the sovereign and creditor receive stochastic endowment streams of tradable goods $y_{t}^{T}$, $y_{t}^{T *}$ and non-tradable goods $y_{t}^{N}, y_{t}^{N *}$. We denote $y_{t}$, a column vector of four income processes: $y_{t}=\left[y_{t}^{T}, y_{t}^{T *}, y_{t}^{N}, y_{t}^{N *}\right]$. It is stochastic, drawn from a compact set $Y=\left[y_{\min }^{T}, y_{\max }^{T}\right] \times\left[y_{\min }^{T *}, y_{\max }^{T *}\right] \times$ $\left[y_{\min }^{N}, y_{\max }^{N}\right] \times\left[y_{\min }^{N *}, y_{\max }^{N *}\right] \subset \mathbb{R}_{+}^{4} \cdot \mu\left(y_{t+1} \mid y_{t}\right)$ is probability distribution of a vector of shocks $y_{t+1}$ conditional on previous realization $y_{t}$. Both sovereign and creditor consume not only non-tradable goods, but also two types of tradable goods endowed in each country. They export their own endowed tradable goods and import tradable goods endowed in the counterpart's country. When the sovereign repays its debt and issues new debt, it can import tradable goods endowed in the creditor's country more than its exports of tradable goods, i.e. having the current account deficit. On the contrary, when the sovereign defaults, it only imports tradable goods endowed in the creditor's country equal to its exports of tradable goods, i.e. having the current account balanced.

The representative creditor is risk-averse. As mentioned above, it is also subject to stochastic income shocks and opts to smooth its consumption through lending/borrowing to the sovereign. The risk-averse creditor prefers to avoid real exchange rate risks and opts to issue bonds in their local

\footnotetext{
${ }^{18}$ Lizarazo (2013) explains that assumption of risk-averse creditors seems to be justified by characteristics of the investors in emerging financial markets. These investors are both individuals and institutional investors such as banks, mutual funds, hedge funds, pension funds and insurance companies. For individual investors, it is straightforward to assume that these agents are risk-averse. For institutional investors, risk aversion may follow from two sources: regulations over the composition of their portfolio and the characteristics of the institutions' management. Regarding the first source, these entities face restrictions on asset allocations; for instance, banks are regulated by capital adequacy ratio. Regarding the second source, for each class of institutional investor, managers ultimately make the portfolio allocation decisions. These managers can also be treated as risk-averse managers.
} 
currency. A large fraction of external debt denominated in foreign currency, shown in Section 3.3, also reflects behavior of a risk-averse creditor. Risk-averseness, rather than risk-neutrality, is necessary for determination of real exchange rate depending not only on the sovereign's but also the creditor's income shocks.

The international capital market is incomplete. The sovereign and creditor can borrow and lend only via one-period, zero-coupon bonds indexed to their consumer price index (CPI), and there are two types of bonds the sovereign (creditor) issues: bonds denominated in local and foreign currency. $b_{t+1}$ $\left(b_{t+1}^{*}\right)$ denotes the amount of bonds to be repaid next period whose set is shown by $B=\left[b_{\min }, b_{\max }\right] \subset$ $\mathbb{R}$ where $b_{\min } \leq 0 \leq b_{\max }$. We set the lower bound at $b_{\min }<-y_{\max }^{T} / \underline{r}^{*}$, which is the largest debt that the sovereign could repay. The upper bound $b_{\max }$ is the high level of assets that the sovereign may accumulate. ${ }^{19}$ The upper bound is the highest level of assets that the sovereign can accumulate, and the lower bound is the highest level of debt that it can hold. We assume $q^{i}\left(b_{t+1}, y_{t}\right)(i \in\{H, F\})$ to be the price of bonds with asset position $b_{t+1}$ and a vector of income shocks $y_{t}$. We assume that $q^{H}$ and $q^{F}$ are denominated in local and foreign currency, respectively. Price functions of both bonds are determined in equilibrium.

We define the current real exchange rate $e_{t}$ as units of local currency against one unit of foreign currency as in Walsh (2003). An increase in $e_{t}$ means one unit of domestic currency buys fewer units of foreign currency. Thus, a rise in $e_{t}$ corresponds to a fall in the value of domestic currency, i.e. depreciation of domestic currency. The real exchange rate is also determined in equilibrium together with bond prices.

We assume that the creditor always commits to repay its debt. However, the sovereign is free to decide whether to repay its debt or to default. If the sovereign chooses to repay its debt, it will preserve its status to issue bonds next period. On the contrary, if it chooses not to pay its debt, it is then subject to both exclusion from the international capital market and direct output costs. The sovereign suffers symmetric output costs on tradable and non-tradable goods. This assumption is consistent with none of the empirical findings justifying asymmetric output costs across tradable and non-tradable sectors in the literature of costs of sovereign defaults. ${ }^{20}$ We consider that the debtor

\footnotetext{
${ }^{19} b_{\max }$ exists when the interest rates on the sovereign's savings are sufficiently low compared to the discount factor, which is satisfied as $\left(1+\underline{r}^{*}\right) \beta<1$.

${ }^{20}$ Though it is within the manufacturing goods sector, not across the tradable and non-tradable goods sectors, Borensztein and Panizza (2010) find that a more export-oriented industry would see its severe growth drop relative to a less export-oriented industry in each year in which the sovereign is in default.
} 
defaults total external debt $\left(b_{t}\right)$. Defaulting total external debt is supported by evidence on recent external debt restructurings, where sovereigns default on both local and foreign currency debt issued at the international market. ${ }^{21}$

When a default is chosen, the sovereign will be in temporary autarky. After being excluded from the market for one period, with exogenous probability $\chi$, it will regain access to the market. Otherwise, it will remain in financial autarky next period.

\subsection{Timing of the Model}

Timing of decisions within each period is summarized in Figure 2.

Figure 2: Timing of the Model

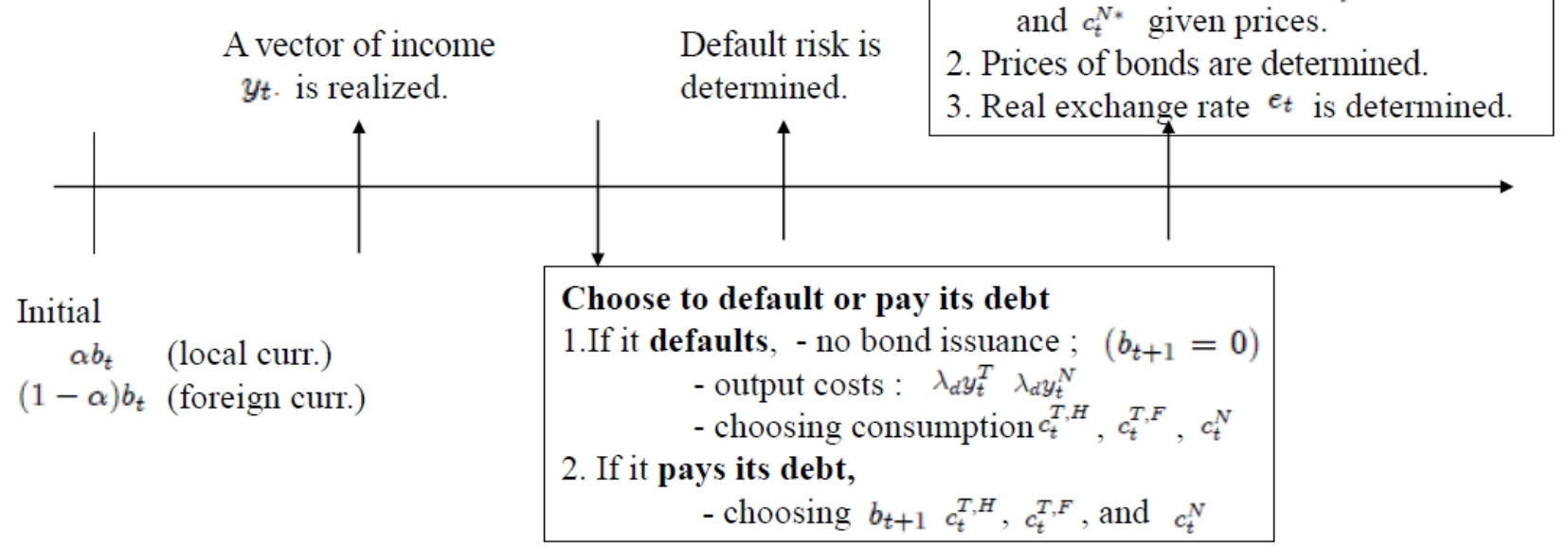

The sovereign starts the current period with total debt $b_{t}$, comprised of local and foreign currency debt. After observing a vector of income shocks $y_{t}$, the sovereign chooses either to pay its debt or to default.

If the sovereign chooses to pay the total debt, given bond price schedules and the real exchange rate, it chooses next period total debt $b_{t+1}$ and current consumption $c_{t}^{T, H}, c_{t}^{T, F}$ and $c_{t}^{N}$. Then, default probability is determined. Given bond prices and the real exchange rate, the creditor chooses $b_{t+1}^{*}$ consistent with the belief of default probability, and consumption $c_{t}^{T *, H}, c_{t}^{T *, F}$, and $c_{t}^{N *}$. Bond prices together with the real exchange rate are determined in equilibrium.

\footnotetext{
${ }^{21}$ There are only a few episodes where sovereigns apparently differentiate creditors of foreign currency and local currency external debt.
} 
On the contrary, if the sovereign opts to default, it suffers direct output costs due to default $\lambda_{d} y_{t}^{T}$ and $\lambda_{d} y_{t}^{N}$. The debtor will be in financial autarky and cannot raise funds at the international capital market this period $\left(b_{t+1}=0\right)$. It simply chooses its current consumption $c_{t}^{T, H}, c_{t}^{T, F}$ and $c_{t}^{N}$. Only the real exchange rate $\left(e_{t}\right)$ is determined at equilibrium.

\subsection{Fixed Share of Foreign Currency Debt}

We explain, succinctly, a rationale of assumption on share of foreign currency debt. Figure 3 shows shares of foreign currency debt in annual frequency before and after defaults and restructurings for 18 episodes from 1999-2013. ${ }^{22}$ We compute shares of foreign currency debt for 18 episodes using data of international bond issuance from Bloomberg and Dealogic. ${ }^{23}$ A majority of countries, which have experienced defaults or restructurings recently, had a large fraction of their external debt, close to 100 percent, denominated in foreign currency both before and after defaults and restructurings. Even among four exceptional cases, three episodes, such as the Dominican Republic in 2004-5, Grenada in 2004-5 and Uruguay in 2003, witnessed a decrease in share of foreign currency denominated debt only after defaults or announcements of restructurings. In addition, these countries seldom changed shares of foreign currency debt, as shown in limited variations over the sample period in Figure $3{ }^{24}$ These clearly support our assumption of fixed and high shares of foreign currency debt.

\footnotetext{
${ }^{22}$ Data on bond issuances for Dominica and St. Kitts and Nevis are not available.

${ }^{23}$ Due to a lack of currency denomination data on loans from Dealogic, our computed shares are based only on bond issuances.

${ }^{24}$ Small variance in share of foreign currency denominated debt over the sample period reported in Table A1 in Appendix C also supports our assumption.
} 
Figure 3: Share of Foreign Currency Debt Before and After Defaults or Announcements of Restructurings

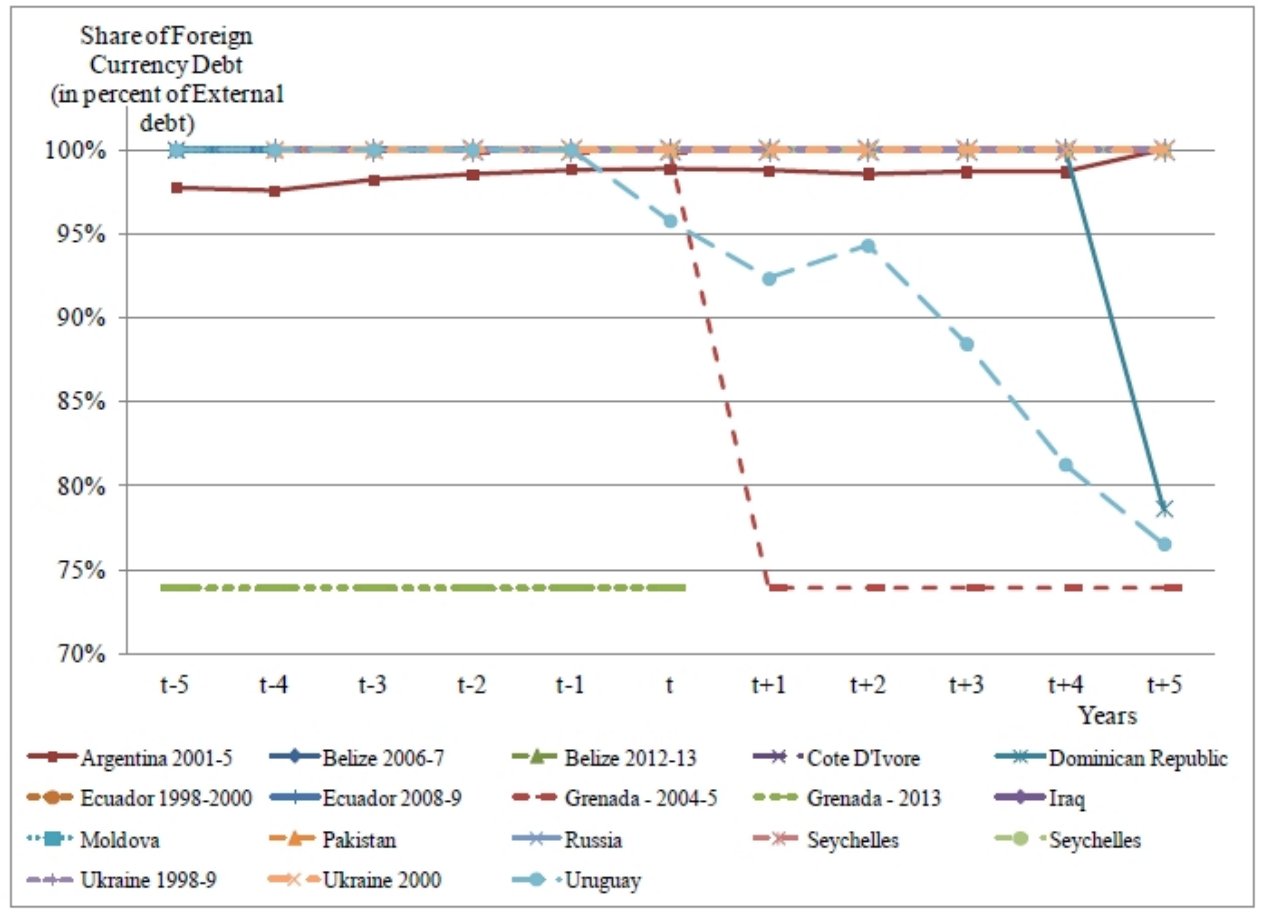

Source: Asonuma and Trebesch (2013), Bloomberg and Dealogic.

\section{Recursive Equilibrium}

In this section, we define the stationary recursive equilibrium of the model. Our framework incorporates three key features: (1) optimal behavior of a risk-averse foreign creditor, (2) two types of external bonds denominated in local and foreign currencies, and (3) endogenous determination of real exchange rate in equilibrium.

\subsection{The Sovereign Country's Problem}

The country's problem is to maximize the expected lifetime utility given by

$$
E_{0} \sum_{t=0}^{\infty} \beta^{t} u\left(c_{t}\right)
$$

A consumption basket $c_{t}$ is defined by the CES aggregates of consumption shown as

$$
c_{t}=\left[\omega^{\frac{1}{\kappa}}\left(c_{t}^{T}\right)^{\frac{\kappa-1}{\kappa}}+(1-\omega)^{\frac{1}{\kappa}}\left(c_{t}^{N}\right)^{\frac{\kappa-1}{\kappa}}\right]^{\frac{\kappa}{\kappa-1}}
$$


where $c_{t}^{T}$ and $c_{t}^{N}$ are consumptions of tradable and non-tradable goods, and $\kappa$ is the elasticity of intratemporal substitutions between these goods. The tradable component is, in turn, comprised of local and foreign-endowed goods in the following manner:

$$
c_{t}^{T}=\left[v^{\frac{1}{\theta}}\left(c_{t}^{T, H}\right)^{\frac{\theta-1}{\theta}}+(1-v)^{\frac{1}{\theta}}\left(c_{t}^{T, F}\right)^{\frac{\theta-1}{\theta}}\right]^{\frac{\theta}{\theta-1}}
$$

where $c_{t}^{T, H}$ and $c_{t}^{T, F}$ are consumptions of traded goods endowed in the country and the creditor's country, respectively. $\theta$ is the elasticity of intratemporal substitution between traded goods endowed in the country and the creditor's country.

Corresponding to the CES bundles of consumption goods, we have an isomorphic price index:

$$
p_{t}=\left[\omega\left(p_{t}^{T}\right)^{1-\kappa}+(1-\omega)\left(p_{t}^{N}\right)^{1-\kappa}\right]^{\frac{1}{1-\kappa}}
$$

where $p_{t}^{T}$ and $p_{t}^{N}$ are prices of traded and non-traded goods. The price of tradable goods is the numeraire $\left(p_{t}^{T}=1\right)$. The tradable good price is, in turn, comprised of prices of local and foreignendowed goods:

$$
1=\left[v\left(p_{t}^{T, H}\right)^{1-\theta}+(1-v)\left(e_{t} p_{t}^{T, F *}\right)^{1-\theta}\right]^{\frac{1}{1-\theta}}
$$

where $p_{t}^{T, H}$ and $p_{t}^{T, F *}$ are prices of traded goods endowed in each country.

Let $V\left(b_{t}, y_{t}\right)$ be the lifetime value function of the country that starts the current period with initial assets $b_{t}$ and a vector of income shocks $y_{t}$. Given sovereign bond prices $q^{i}\left(b_{t+1}, y_{t}\right) i=H, F$ and the real exchange rate $e_{t}$, the country solves its optimization problem.

If the country decides to pay its debt, it chooses its next-period assets $\left(b_{t+1}\right)$ and current consumption after paying back its initial debt. On the contrary, if the country defaults, it will not be able to issue bonds in the current period. It simply chooses current consumption.

Given its option to default, $V\left(b_{t}, y_{t}\right)$ satisfies

$$
V\left(b_{t}, y_{t}\right)=\max \left[V^{R}\left(b_{t}, y_{t}\right), V^{D}\left(y_{t}\right)\right]
$$


where $V^{R}\left(b_{t}, y_{t}\right)$ is its value, which the country chooses to pay debt given as

$$
\begin{gathered}
V^{R}\left(b_{t}, y_{t}\right)=\max _{c_{t}^{T, H}, c_{t}^{T, F}, c_{t}^{N}, b_{t+1}} u\left(c_{t}\right)+\beta \int_{Y} V\left(b_{t+1}, y_{t+1}\right) d \mu\left(y_{t+1} \mid y_{t}\right) \\
\text { s.t. } p_{t}^{T, H} c_{t}^{T, H}+e_{t} p_{t}^{T, F} c_{t}^{T, F}+p_{t}^{N} c_{t}^{N}+p_{t}\left[q^{H}\left(b_{t+1}, y_{t}\right) \alpha+e_{t} q^{F}\left(b_{t+1}, y_{t}\right)(1-\alpha)\right] b_{t+1} \\
=p_{t}^{T, H} y_{t}^{T}+p_{t}^{N} y_{t}^{N}+p_{t}\left[\alpha+e_{t}(1-\alpha)\right] b_{t}
\end{gathered}
$$

$$
\text { s.t. } \quad(4) \quad \& \quad(5)
$$

and $V^{D}\left(y_{t}\right)$ is the value, which the country decides to default, shown as

$$
\begin{gathered}
V^{D}\left(y_{t}\right)=\max _{c_{t}^{T, H}, c_{t}^{T, F}, c_{t}^{N}} u\left(c_{t}\right)+\beta\left[\chi \int_{Y} V\left(0, y_{t+1}\right) d \mu\left(y_{t+1} \mid y_{t}\right)+(1-\chi) \int_{Y} V^{D}\left(y_{t+1}\right) d \mu\left(y_{t+1} \mid y_{t}\right)\right] \\
\text { s.t. } \quad p_{t}^{T, H} c_{t}^{T, H}+e_{t} p_{t}^{T, F} c_{t}^{T, F}+p_{t}^{N} c_{t}^{N}=\left(1-\lambda_{d}\right) p_{t}^{T, H} y_{t}^{T}+\left(1-\lambda_{d}\right) p_{t}^{N} y_{t}^{N}
\end{gathered}
$$

$$
\text { s.t. (4) \& (5) }
$$

where $V\left(0, y_{t+1}\right)$ is its value next period with no initial debt. $\lambda_{d} p_{t}^{T, H} y_{t}^{T}$ and $\lambda_{d} p_{t}^{N} y_{t}^{N}$ express output costs, which the country suffers due to a default. When the country decides the next-period assets, it also takes into consideration impacts of the real exchange rate, which is determined by optimality conditions of the sovereign debtor and the creditor.

The country's default policy can be characterized by default set $D\left(b_{t}\right) \subset Y$. The default set is a set of income vectors $y$ 's for which default is optimal given the debt position $b_{t}$.

$$
D\left(b_{t}\right)=\left\{y_{t} \in Y: V^{R}\left(b_{t}, y_{t}\right)<V^{D}\left(y_{t}\right)\right\}
$$

In the case where the country chooses to pay its debt, we obtain the following optimality conditions:

$$
\frac{c_{t}^{T}}{c_{t}^{N}}=\left(\frac{\omega}{1-\omega}\right)\left(\frac{1}{p_{t}^{N}}\right)^{-\kappa}
$$




$$
\begin{gathered}
\frac{c_{t}^{T, H}}{c_{t}^{T, F}}=\left(\frac{v}{1-v}\right)\left(\frac{p_{t}^{T, H}}{e_{t} p_{t}^{T, F}}\right)^{-\theta} \\
{\left[q^{H}\left(b_{t+1}, y_{t}\right) \alpha+e_{t} q^{F}\left(b_{t+1}, y_{t}\right)(1-\alpha)\right]=E_{t}\left[\beta \frac{u^{\prime}\left(c_{t+1}\right)}{u^{\prime}\left(c_{t}\right)} 1_{\text {Non-Default }}\left[\alpha+e_{t+1}(1-\alpha)\right]\right]}
\end{gathered}
$$

On the contrary, if the country chooses to default, we have equation (12) and (13), not (14).

\subsection{The Foreign Creditor's Problem}

The foreign creditor is also risk-averse and behaves competitively at the market. The problem is maximizing its expected lifetime utility given by

$$
E_{0} \sum_{t=0}^{\infty}\left(\beta^{*}\right)^{t} u\left(c_{t}^{*}\right)
$$

Its consumption basket $c_{t}^{*}$ is similar to that of the country:

$$
c_{t}^{*}=\left[\left(\omega^{*}\right)^{\frac{1}{\kappa}}\left(c_{t}^{T *}\right)^{\frac{\kappa-1}{\kappa}}+\left(1-\omega^{*}\right)^{\frac{1}{\kappa}}\left(c_{t}^{N *}\right)^{\frac{\kappa-1}{\kappa}}\right]^{\frac{\kappa}{\kappa-1}}
$$

where $c_{t}^{T *}$ and $c_{t}^{N *}$ are consumptions of traded and non-traded goods. Tradable goods consumption is composed of consumptions of two tradable goods: $c_{t}^{T *, H}$ and $c_{t}^{T *, F}$ :

$$
c_{t}^{T *}=\left[\left(v^{*}\right)^{\frac{1}{\theta}}\left(c_{t}^{T *, H}\right)^{\frac{\theta-1}{\theta}}+\left(1-v^{*}\right)^{\frac{1}{\theta}}\left(c_{t}^{T *, F}\right)^{\frac{\theta-1}{\theta}}\right]^{\frac{\theta}{\theta-1}}
$$

Corresponding to the CES bundles of consumption goods, we have an isomorphic price index:

$$
p_{t}^{*}=\left[\left(\omega^{*}\right)\left(p_{t}^{T^{*}}\right)^{1-\kappa}+\left(1-\omega^{*}\right)\left(p_{t}^{N *}\right)^{1-\kappa}\right]^{\frac{1}{1-\kappa}}
$$

where $p_{t}^{T *}$ and $p_{t}^{N *}$ are prices of traded and non-traded goods. The tradable goods price of the creditor is similar to that of the country shown as:

$$
p_{t}^{T *}=\left[\left(1-v^{*}\right)\left(\frac{p_{t}^{T, H}}{e_{t}}\right)^{1-\theta}+v^{*}\left(p_{t}^{T, F}\right)^{1-\theta}\right]^{\frac{1}{1-\theta}}
$$

If the country repays its debt, the creditor also decides its assets for next period $\left(b_{t+1}^{*}\right)$ and current 
consumption $c_{t}^{T *, H}, c_{t}^{T *, F}$, and $c_{t}^{N *}$ subject to its budget constraint, such as

$\frac{p_{t}^{T, H}}{e_{t}} c_{t}^{T *, H}+p_{t}^{T, F} c_{t}^{T *, F}+p_{t}^{N *} c_{t}^{N *}+p_{t}^{*}\left[\begin{array}{c}\frac{q^{H}\left(b_{t+1}, y_{t}\right)}{e_{t}} \alpha \\ +q^{F}\left(b_{t+1}, y_{t}\right)(1-\alpha)\end{array}\right] b_{t+1}^{*}=p_{t}^{T *, F} y_{t}^{T *}+p_{t}^{N *} y_{t}^{N *}+p_{t}^{*}\left[\frac{1}{e_{t}} \alpha+(1-\alpha)\right] b_{t}^{*}$

Then, we obtain the following optimality conditions:

$$
\begin{aligned}
& \frac{c_{t}^{T *}}{c_{t}^{N *}}=\left(\frac{\omega^{*}}{1-\omega^{*}}\right)\left(\frac{p_{t}^{T *}}{p_{t}^{N *}}\right)^{-\kappa} \\
& \frac{c_{t}^{T *, F}}{c_{t}^{T *, H}}=\left(\frac{v^{*}}{1-v^{*}}\right)\left(\frac{p_{t}^{T, F}}{p_{t}^{T, H} / e_{t}}\right)^{-\theta} \\
& {\left[\frac{q^{H}\left(b_{t+1}, y_{t}\right)}{e_{t}} \alpha+q^{F}\left(b_{t+1}, y_{t}\right)(1-\alpha)\right]=E_{t}\left[\beta^{*} \frac{u^{\prime}\left(c_{t+1}^{*}\right)}{u^{\prime}\left(c_{t}^{*}\right)} 1_{\text {Non-Default }}\left[\frac{1}{e_{t+1}} \alpha+(1-\alpha)\right]\right] }
\end{aligned}
$$

If the country defaults, the creditor maximizes its utility by choosing current consumption $c_{t}^{T *, H}$, $c_{t}^{T *, F}$, and $c_{t}^{N *}$ subject to its budget constraint:

$$
\frac{p_{t}^{T, H}}{e_{t}} c_{t}^{T *, H}+p_{t}^{T, F} c_{t}^{T *, F}+p_{t}^{N *} c_{t}^{N *}=p_{t}^{T *, F} y_{t}^{T *}+p_{t}^{N *} y_{t}^{N *}
$$

Then, we have we have equation (21) and (22), not (23).

\subsection{Bond Prices and Real Exchange Rate}

Bond prices indexed to the sovereign's and creditor's CPI $q^{i}\left(b_{t+1}, y_{t}\right)$ for $i=H, F$ are functions of the next-period assets and a vector of income shocks. If the country chooses to pay its debt, the creditor receives payoffs equal to the face value of bonds, which is normalized to 1 . If the country chooses to default, payoffs are zero. We derive bond price functions for both the sovereign's and the creditor's Euler equations, which take into account the sovereign's decision of paying its debt and defaulting.

$$
\begin{gathered}
{\left[q^{H}\left(b_{t+1}, y_{t}\right) \alpha+e_{t} q^{F}\left(b_{t+1}, y_{t}\right)(1-\alpha)\right]=E_{t}\left[\beta \frac{u^{\prime}\left(c_{t+1}\right)}{u^{\prime}\left(c_{t}\right)} 1_{\text {Non-Default }}\left[\alpha+e_{t+1}(1-\alpha)\right]\right]} \\
{\left[\frac{q^{H}\left(b_{t+1}, y_{t}\right)}{e_{t}} \alpha+q^{F}\left(b_{t+1}, y_{t}\right)(1-\alpha)\right]=E_{t}\left[\beta^{*} \frac{u^{\prime}\left(c_{t+1}^{*}\right)}{u^{\prime}\left(c_{t}^{*}\right)} 1_{\text {Non-Default }}\left[\frac{1}{e_{t+1}} \alpha+(1-\alpha)\right]\right]}
\end{gathered}
$$


The real exchange rate is defined as relative CPI between the sovereign and the creditors as

$$
e_{t}=\frac{p_{t}}{p_{t}^{*}}
$$

\subsection{Market Clearing Conditions for Goods and Bonds}

If the country repays its debt in the current period, market clearing conditions for tradable goods and non-tradable goods are

$$
\begin{gathered}
c_{t}^{T, H}+c_{t}^{T *, H}=y_{t}^{T} \\
c_{t}^{T, F}+c_{t}^{T *, F}=y_{t}^{T *} \\
c_{t}^{N}=y_{t}^{N} \\
c_{t}^{N *}=y_{t}^{N *}
\end{gathered}
$$

On the contrary, in the case of default, the following are market clearing conditions for tradable goods and non-tradable goods endowed in the country.

$$
\begin{gathered}
c_{t}^{T, H}+c_{t}^{T *, H}=\left(1-\lambda_{d}\right) y_{t}^{T} \\
c_{t}^{N}=\left(1-\lambda_{d}\right) y_{t}^{N}
\end{gathered}
$$

Market clearing condition for bonds is

$$
\pi b_{t}+(1-\pi) b_{t}^{*}=0
$$

where $\pi$ denotes the size of the sovereign economy relative to the creditor.

\subsection{Recursive Equilibrium}

We define a stationary equilibrium in the model.

Definition 1 A recursive equilibrium is a set of functions for (A) the country's value func-

tion $V\left(b_{t}, y_{t}\right)$; consumption, $c_{t}^{T, H}\left(b_{t}, y_{t}\right), c_{t}^{T, F}\left(b_{t}, y_{t}\right), c_{t}^{N}\left(b_{t}, y_{t}\right)$; asset position $b_{t+1}\left(b_{t}, y_{t}\right)$ and default set $D\left(b_{t}\right) ;(B)$ foreign creditor's consumption $c_{t}^{T *, H}\left(b_{t}, y_{t}\right), c_{t}^{T *, F}\left(b_{t}, y_{t}\right), c_{t}^{N *}\left(b_{t}, y_{t}\right)$; asset position 
$b_{t+1}^{*}\left(b_{t}, y_{t}\right)$; and $(C)$ bond prices $q^{i}\left(b_{t+1}, y_{t}\right)$ for $i=H, F$ and the real exchange rate $e_{t}\left(b_{t+1}, y_{t}\right)$ such that

[1] Given bond prices and the real exchange rate, the country's value function $V\left(b_{t}, y_{t}\right)$; consumption, $c_{t}^{T, H}\left(b_{t}, y_{t}\right), c_{t}^{T, F}\left(b_{t}, y_{t}\right), c_{t}^{N}\left(b_{t}, y_{t}\right)$; asset position $b_{t+1}\left(b_{t}, y_{t}\right)$; and default set $D\left(b_{t}\right)$ satisfy the country's optimization problem.

[2] Given bond prices and the real exchange rate, the creditor's consumption $c_{t}^{T *, H}\left(b_{t}, y_{t}\right), c_{t}^{T *, F}\left(b_{t}, y_{t}\right)$, $c_{t}^{N *}\left(b_{t}, y_{t}\right)$ and asset position $b_{t+1}^{*}\left(b_{t}, y_{t}\right)$ satisfy the creditor's optimization problem.

[3] Bond bond prices $q^{i}\left(b_{t+1}, y_{t}\right)$ for $i=H, F$ and the real exchange rate $e_{t}\left(b_{t+1}, y_{t}\right)$ satisfy optimality conditions of two parties.

[4] Market clearing conditions for goods and bonds are satisfied.

In equilibrium, default probability $p\left(b_{t+1}, y_{t}\right)$ is related to the sovereign's default decision in the following manner:

$$
p\left(b_{t+1}, y_{t}\right)=\int_{D^{*}\left(b_{t+1}\right)} d \mu\left(y_{t+1} \mid y_{t}\right)
$$

Risk-free interest rate is defined as

$$
\frac{1}{1+r^{*}\left(b_{t+1}, y_{t}\right)}=\beta^{*} E_{t}\left[\frac{u^{\prime}\left(c_{t+1}^{*}\right)}{u^{\prime}\left(c_{t}^{*}\right)}\right]
$$

We define total spreads for domestic and foreign currency debt evaluated by the creditor's side as follows:

$$
\begin{aligned}
& s^{H}\left(b_{t+1}, y_{t}\right)=\frac{e_{t}}{q^{H}\left(b_{t+1}, y_{t}\right)}-1-r^{*}\left(b_{t+1}, y_{t}\right) \\
& s^{F}\left(b_{t+1}, y_{t}\right)=\frac{1}{q^{F}\left(b_{t+1}, y_{t}\right)}-1-r^{*}\left(b_{t+1}, y_{t}\right)
\end{aligned}
$$

\section{Quantitative Analysis}

This section provides quantitative analysis of model. Our major findings can be summarized as follows. First, at the steady state distribution, we show that at any level of tradable goods, the real exchange rate tends to depreciate sharply when the sovereign defaults. Moreover, the real exchange rate depreciates when the sovereign receives a low tradable goods shock. Second, our simulation exercise uses Argentine default in 2001 and replicates both business cycle and non-business cycle 
regularities, including moments of the real exchange rates in both pre-default and post-default periods. Lastly, most importantly, the model generates the link between real exchange rate dynamics and default choices (default probability) around default.

\subsection{Parameters and Functional Forms,}

We use most of the parameters and functional forms specified in previous work. There are three new elements in the model associated with a two-country, four-goods set-up: (i) relative size of the sovereign, (ii) weights on consumption of home-endowed tradable goods, and (iii) share of domestic currency debt.

The following utility functions are used in numerical simulation:

$$
u\left(c_{t}\right)=\frac{c_{t}^{1-\sigma}}{1-\sigma}, \quad u\left(c_{t}^{*}\right)=\frac{c_{t}^{* 1-\sigma}}{1-\sigma}
$$

where $\sigma$ expresses degree of risk aversion. We set $\sigma$ equal to 2, which is commonly used in real business cycle analysis for advanced economy and emerging markets. The creditor's discount factor is set to $\beta^{*}=0.982$ to replicate the risk-free interest rate of $1.7 \% .^{25}$ The elasticity of substitution between tradable and non-tradable consumption is taken from Gonzales and Neumeyer (2003) where they estimate the elasticity for Argentina to be equal to 0.48. We assume an elasticity of substitution between tradable goods endowed in the sovereign and the creditor country $\theta$, of 2 , as in Benigno and Thoenissen (2008). Weights of tradable goods consumption and home-endowed tradable goods consumptions are set to $\omega=0.51, \omega^{*}=0.5$ and $v=v^{*}=0.5$ in order to have the price of tradable goods at steady-state distribution $\left(p^{T}=1\right)$.

The probability of re-entry to credit markets after defaults is set at $\chi=0.282$, which is consistent with observed evidence regarding the exclusion from credit markets of defaulting countries mentioned in Gelos et al (2011). Output loss parameter $\lambda_{d}$ is assumed to be $2 \%$ following Sturzenegger (2002)'s estimates.

We assume each exogenous endowment stream $y_{t}^{i}$ for $i=\left\{T, N, T^{*}, N^{*}\right\}$ follows a log-normal

\footnotetext{
${ }^{25}$ Similarly, Lizarazo (2013) set the creditor's discount rate as $\beta^{*}=0.98$ to generate the international interest rate of $1.7 \%$.
} 
$\mathrm{AR}(1)$ process where innovations to the shocks are allowed to be correlated:

$$
\log \left(y_{t}^{i}\right)=\log \left(\bar{y}^{i}\right)+\rho_{y}^{i}\left(\log \left(y_{t-1}^{i}\right)-\log \left(\bar{y}^{i}\right)\right)+\epsilon_{y}^{i}
$$

where $\bar{y}^{i}$ is the mean income, $E\left[\epsilon_{y}^{i}\right]=0$ for $i=\left\{T, N, T^{*}, N^{*}\right\}$ and the variance-covariance matrix of the error terms is the following:

$$
E\left[\epsilon^{\prime} \epsilon\right]=\left[\begin{array}{cccc}
\sigma^{T} & \sigma^{T N} & \sigma^{T T *} & \sigma^{T N *} \\
\sigma^{T N} & \sigma^{N} & \sigma^{N T *} & \sigma^{N N *} \\
\sigma^{T T *} & \sigma^{N T *} & \sigma^{T *} & \sigma^{T * N *} \\
\sigma^{T N *} & \sigma^{N N *} & \sigma^{T * N *} & \sigma^{N *}
\end{array}\right]=\left[\begin{array}{cccc}
0.0027 & 0.0019 & 0 & 0 \\
0.0019 & 0.0019 & 0 & 0 \\
0 & 0 & 0.0006 & 0.0002 \\
0 & 0 & 0.0002 & 0.0002
\end{array}\right]
$$

where $\epsilon=\left[\epsilon_{y}^{T}, \epsilon_{y}^{N}, \epsilon_{y}^{T *}, \epsilon_{y}^{N *}\right]^{\prime}$. Auto-correlation coefficients and the variance-covariance matrix are computed from the quarterly real GDP data of Argentina from 1993Q1 to 2011Q4 (sovereign) and of the US from 1988Q1 to 2011Q4. Sector-level GDP data are seasonally adjusted and are taken from the Ministry of Economy and Production (MECON) and the US Bureau of Economic Analysis (BEA). The sectoral classification into tradable and non-tradable goods follows the traditional approach adopted in real business cycle literature. The tradable goods sector comprises "manufacturing" and the primary sectors, whereas the non-tradable goods sector is composed of remaining sectors. The data are detrended using Hodrick-Prescott filter with a smoothing parameter of 1600. Each shock is then discretized into a finite state Markov chain by using a quadrature procedure in Hussey and Tauchen (1991) from their joint distribution. We obtain estimated coefficients such as $\rho^{T}=0.59$ and $\rho^{N}=0.70$ for Argentina and $\rho^{T *}=0.49$ and $\rho^{N *}=0.67$ for the US.

For remaining country-specific parameters, size of the sovereign relative to that of the creditor is set to 0.025 to reflect the ratio of US dollar GDP of Argentina to that of the US over the period 1993-2012. Sturzenegger and Zettelmeyer (2006) report that Argentina experienced 6 defaults in 1820-2004. We specify the sovereign's discount factor $\beta=0.86$ (Argentina) to replicate the average default frequency of $3.4 \%$. The share of domestic currency debt is set at 0.01 based on the average share over the period 1996-2006 from Bloomberg and Dealogic. 
Table 3: Model Parameters

\begin{tabular}{lll} 
Parameter & Value & Sources \\
\hline \hline General & & \\
\hline Risk aversion & $\sigma=2$ & RBC literature \\
\hline Elast. of sub. b/w $c^{T}, c^{T *}$ & $\kappa=0.48$ & Gonzales and Neumeyer (2003) \\
\hline Elast. of sub. b/w $c^{T, H}, c^{T *, F}$ & $\theta=2$ & Benign and Thoenissen (2008) \\
\hline Weight of $c^{T}, c^{T *}$ in CES & $\omega=0.51, \omega^{*}=0.50$ & Computed \\
\hline Weight of $c^{T, H}, c^{T *}, F$ in CES & $v=v^{*}=0.5$ & Computed \\
\hline Probability of reentry & $\chi=0.282$ & Gelos et al (2011) \\
\hline Output cost & $\lambda_{d}=0.02$ & Sturzenegger (2002) \\
\hline Discount rate - Creditor & $\beta^{*}=0.982$ & Computed \\
\hline Autoreg. of income - creditor & $\rho^{N *}=0.67, \rho^{T *}=0.49$ & Computed - US BEA \\
\hline Sovereign specific & & Computed - MECON, \\
\hline Autoreg. of income - country & $\rho^{N}=0.70, \rho^{T}=0.59$ & IMF WEO \\
\hline Relative size of sovereign & $\pi=0.025$ & Computed \\
\hline Discount rate & $\beta=0.86$ & Bloomberg/Dealogic \\
\hline Share of dome. curre. debt & $\alpha=0.01$ & \\
\hline
\end{tabular}

\subsection{Numerical Results on Equilibrium Properties}

In this subsection, we cover the equilibrium properties of the model. Figure 4 shows that the default probability at mean level of tradable goods is weakly increasing with respect to the level of total debt. Furthermore, default probability is weakly increasing respect to level of tradable goods. These two findings are consistent with recent quantitative analysis of sovereign debt - as in Aguiar and Gopinath (2006), Arellano (2008) and Yue (2010) - that the sovereign is more likely to default when it has accumulated its debt and a bad income shock. 
Figure 4: Default Probability

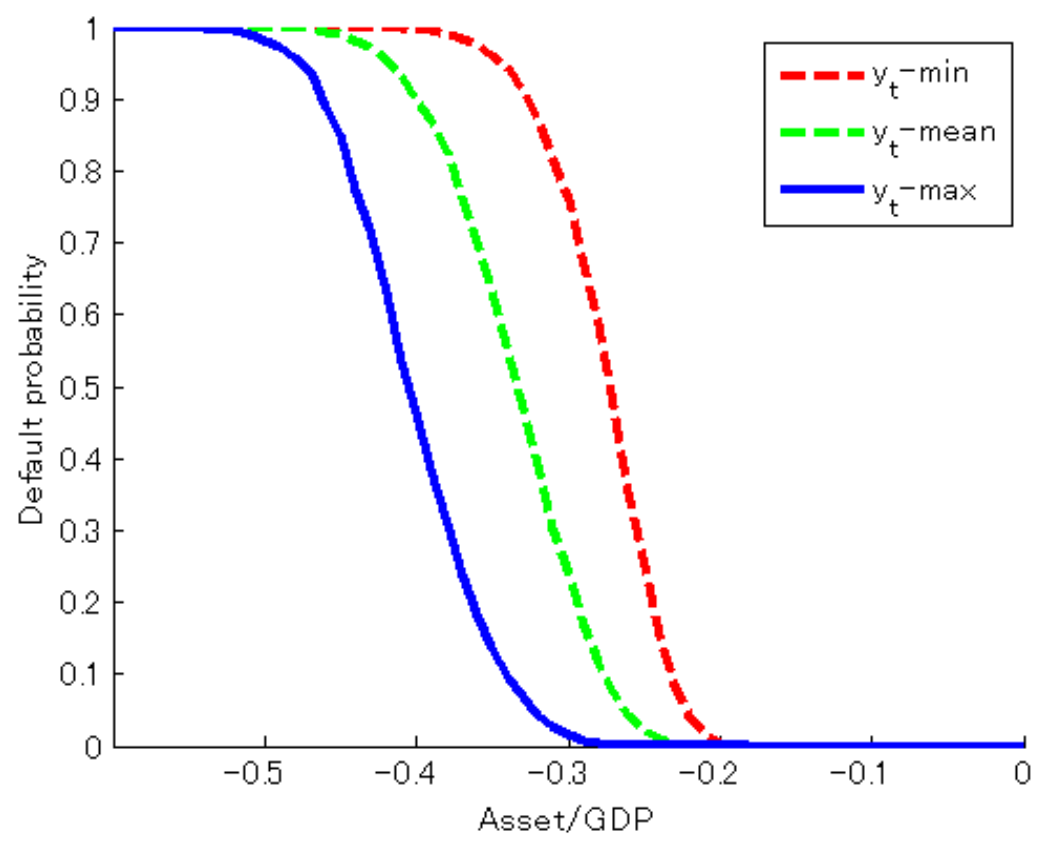

Figure 5: Real Exchange Rates

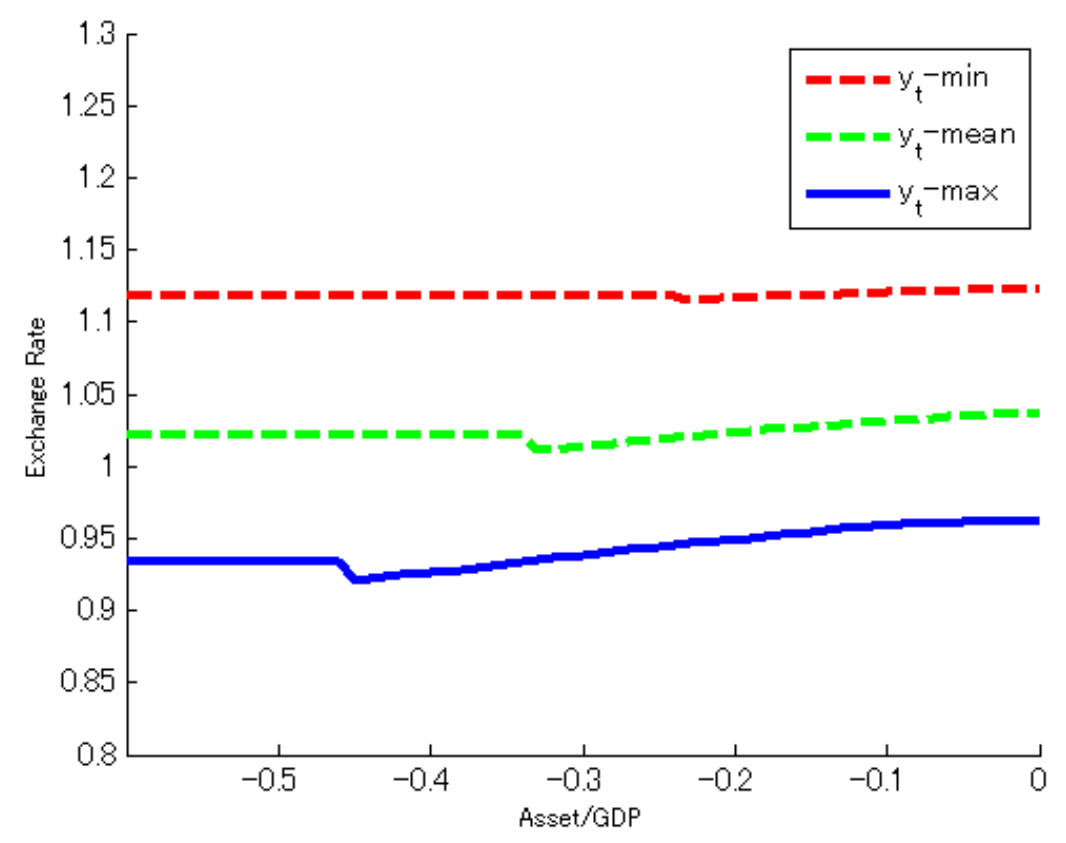

Figure 5 displays that, at a given level of tradable goods below threshold of debt/GDP ratio where the sovereign opts to default, a low level of real exchange rate meaning appreciation is associated with a high current debt/GDP ratio. With fixed tradable goods income shock, higher current debt leads 
to lower consumption of tradable goods (with less tradable goods endowment left for consumption) indicating higher marginal utility of consumption. This, in turn, results in both the lower price of tradable goods and the lower overall price. On the contrary, when the sovereign defaults at current debt, the real exchange rate tends to depreciate. By defaulting, the sovereign prefers to have higher consumption of tradable goods, indicating lower marginal utility of consumption, which leads to both a higher price of non-traded goods and a higher overall price level.

Moreover, the level of the real exchange rate is high implying depreciation when the sovereign has a low level of traded goods. With a low level of traded goods, the sovereign tends to accumulate higher debt which leads to an increase in default probability. Then, the real exchange rate depreciates and is associated with an increase in default probability. Price functions for newly-issued debt and debt level are shown in Appendix C.

\subsection{Simulation - Argentina}

We conduct 1000 rounds of simulations, with 2000 periods per round and then extract the last 200 periods to analyze features evaluated at the steady-state distribution. In the last 200 periods, we choose 40 observations before and after a default event to compare with moments in data for Argentina. The second column in Table 4 and 5 summarizes moments of data. ${ }^{26}$ Output data are seasonally adjusted from the MECON for 1993Q1-2001Q3 and 2001Q4-2011Q4. Trade balance is calculated as ratio to GDP. Argentina's external debt data are from the IMF WEO for 1993-2001 and 2002-2011. We calculate two measures of the sovereign's indebtedness; the first measure is the average external debt to GDP ratio. We also compute the ratio of the country's debt service (including shortterm debt) to its GDP for Argentina. Bond spreads are from the J.P. Morgan's Emerging Market Bond Index (EMBI) Global for Argentina for 1998Q1-2001Q3 and 2001Q4-2011Q4. Real exchange rate is computed based on monthly Argentina nominal exchange rates against the US dollar, Argentina CPI, and US CPI from IMF IFS for 1993Q1-2001Q3 and 2001Q4-2011Q4. We compare our simulation results with those of Aguiar and Gopinath (2006) and Arellano (2008).

As is obvious in Table 5, the model matches business cycle statistics in data in both pre-default and post-default periods. Our model replicates volatile consumption and trade balance/GDP volatility, both of which are prominent features of emerging economy business cycle models as in Aguilar and

\footnotetext{
${ }^{26}$ See also Arellano (2008) and Yue (2010) for similar treatment of simulation.
} 
Gopinath (2007) and Neumeyer and Perri (2005). Trade balance/output standard deviation in the model is much higher than that of data because trade balance in our model also includes variations of imports merely driven by real exchange rate fluctuations. Moreover, it also generates a negative correlation between trade balance and output.

Table 4: Business Cycle Statistics for Argentina

\begin{tabular}{lllll} 
& Data & Model & A and G (2006) & Arellano (2008) \\
\hline \hline Before Default & & & & \\
\hline Consumption Std/Output Std & 1.14 & 1.65 & 1.06 & 1.10 \\
\hline Trade balance/Output Std. Dev. (\%) & 0.38 & 2.96 & 0.21 & 0.26 \\
\hline Corr. (Trade Balance/GDP, Output) & -0.87 & -0.10 & -0.18 & -0.25 \\
\hline After Default & & & & - \\
\hline Consumption Std/Output Std & 1.14 & 1.65 & - & - \\
\hline Trade balance/Output Std. Dev. (\%) & 0.40 & 3.05 & - & - \\
\hline Corr. (Trade Balance/GDP, Output) & -0.92 & -0.04 & - & \\
\hline Source: Aguiar and Gopinath (2006) and Arellano (2008), MECON
\end{tabular}

On non-business cycle statistics, the model shows relations among bond spreads, debt/GDP ratio and output, as in the data in both pre-default and post-default periods. Bond spreads are positively correlated with debt/GDP ratio, but negatively correlated with output. This is because default probability is high, leading to higher spreads when debt/GDP ratio is high and output is low. Our simulation also reproduces similar levels of average bonds spreads and volatility of spreads in both pre-default and post-default periods, though simulated moments in post-default periods are closer to those in the data. However, we see some deviations of average debt/GDP ratio from the total debt service/GDP ratio in data in both pre-default and post-default periods.

What makes our model unique compared to previous studies is that our model generates four new statistics of the real exchange rate which match with the data. Among four moments, it is noteworthy that the current model replicates a higher average real exchange rate in the post-default period than in the pre-default periods, as observed in the data. We also explain that the real exchange rate negatively correlates with output, but positively correlates with spreads in both the pre-default and post-default periods. Simulated real exchange rate volatility is $9.6 \%$, close to data $(5.0 \%)$ in the 
pre-default period, whereas it is $9.4 \%$, much lower than data $(27.6 \%)$ in the post-default period.

Table 5: Non-Business Cycle Statistics for Argentina (in quarterly frequency) ${ }^{1}$

Data Model A and G (2006) Arellano (2008)

\begin{tabular}{|c|c|c|c|c|}
\hline \multicolumn{5}{|l|}{ Target Statistics } \\
\hline Default Probability & 3.3 & 3.4 & 0.92 & 3.0 \\
\hline \multicolumn{5}{|l|}{ Non-target Statistics } \\
\hline \multicolumn{5}{|l|}{ Before Default } \\
\hline Average Debt/GDP ratio & $45.4 / 8.0$ & 13.5 & - & 5.95 \\
\hline Corr. (Spreads, Output) ${ }^{2}$ & -0.62 & -0.19 & -0.29 & -0.29 \\
\hline Average Bond Spreads ${ }^{2}$ & 7.6 & 5.9 & & 3.58 \\
\hline Bond Spreads Std. Deviations $(\%)^{2}$ & 2.7 & 5.8 & 8.00 & 6.38 \\
\hline Corr. (Debt/GDP, Spreads) ${ }^{2}$ & $0.92 / 0.93$ & 0.38 & & - \\
\hline Average Real Exchange Rate ${ }^{3}$ & 0.95 & 0.98 & & - \\
\hline Real Exchange Rate Std. Deviations (\%) & 4.7 & 9.4 & & - \\
\hline Corr. (Exchange, Output) & -0.56 & -0.18 & & \\
\hline Corr. (Exchange, Spreads) ${ }^{2}$ & 0.62 & 0.84 & & \\
\hline \multicolumn{5}{|l|}{ After Default } \\
\hline Average Debt/GDP ratio & $75.3 / 19.8$ & 11.7 & & - \\
\hline Corr. (Spreads, Output) ${ }^{4}$ & -0.73 & -0.16 & & - \\
\hline Average Bond Spreads ${ }^{4}$ & $6.7 / 22.9$ & 6.2 & & - \\
\hline Bond Spreads Std. Deviations ${ }^{4}$ & $4.0 / 23.1$ & 5.9 & & - \\
\hline Corr. (Debt/GDP, spreads) ${ }^{4}$ & $0.95 / 0.83$ & 0.32 & & - \\
\hline Average Real Exchange Rate ${ }^{3}$ & 2.23 & 1.05 & & - \\
\hline Real Exchange Rate Std. Deviations (\%) & 31.5 & 9.5 & & - \\
\hline Corr. (Exchange, Output) & -0.65 & -0.20 & & \\
\hline Corr. (Exchange, Spreads) ${ }^{4}$ & 0.55 & 0.74 & & \\
\hline
\end{tabular}

Source: Aguiar and Gopinath (2006), Arellano (2008), Datastream, IMF IFS and WEO, MECON

${ }^{1}$ Spreads corresponds to spreads on foreign currency denominated bonds.

2 Data for spreads are from 1997Q1 to 2001Q4 for Argentina. 


\footnotetext{
3 Over 10 quarters

4 Excluding autarky periods.
}

Figure 6 contrasts the simulated process with the actual dynamics of the real exchange rate of Argentina before and after default. We replicate two features of real exchange rate movements around defaults. In the model, before defaults, the sovereign receiving a series of low traded goods shocks, tends to accumulate more debt and faces real exchange rate depreciation. Since a majority of debt is denominated in foreign currency, this, in turn, increases the burden of payments in terms of local currency, increasing default probability and forcing the sovereign to default. Once the sovereign declares default, it suffers output costs due to default and loses access to the market. By defaulting, the sovereign enjoys higher consumption of traded goods, indicating a lower marginal utility of consumption, which leads to both a higher price of non-traded goods and a higher overall price level. Thus, it results in a further depreciation of the real exchange rate. This mechanism drives the equilibrium depreciation of real exchange rate in the model and it is a plausible explanation of observed pattern in the data.

Figure 6: Real Exchange Rates Dynamics

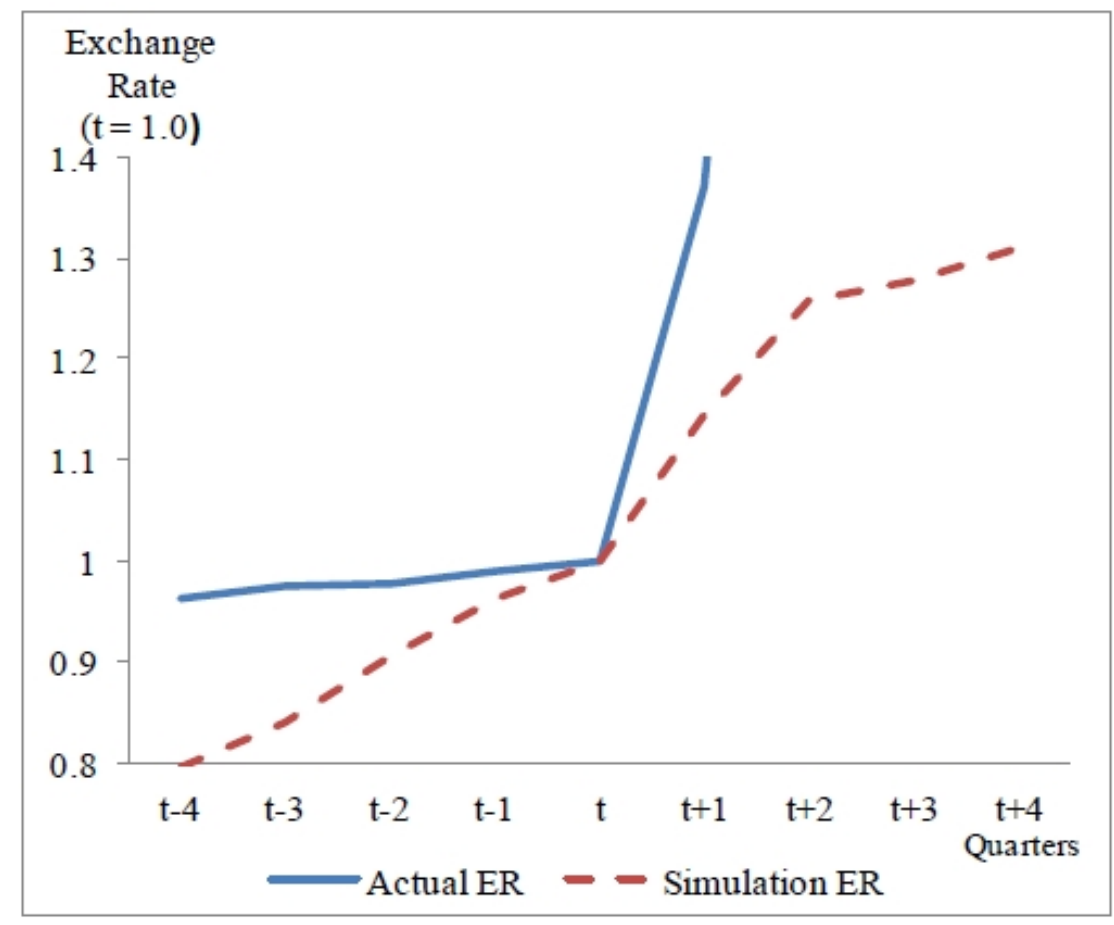

Source: Author's computation and IMF IFS 
We compare simulated moments of spreads on domestic and foreign currency bonds in the postdefault periods with data. ${ }^{27}$ The current model replicates a common feature that average spreads on domestic currency bonds are higher than those of foreign currency bonds, incorporating real exchange rate fluctuations as we see in the data. Average bond spreads for domestic currency bonds in our model are three times as high as those of foreign currency bonds. In addition, we also generate much more volatile domestic currency bonds than foreign currency bonds as observed in the data. Both real exchange rate fluctuations and investor risk aversion interact and produce high and volatile domestic currency bond spreads.

Table 6: Statistics for Bond Spreads in Post-default Periods

\begin{tabular}{lll} 
After Default & Data $^{1}$ & Model \\
\hline \multicolumn{2}{l}{ Domestic currency debt } & \\
\hline Average Bond Spreads & 26.4 & 20.3 \\
\hline Bond Spreads Std. Dev.(\%) & 15.7 & 10.5 \\
\hline Foreign currency debt & $6.7 / 22.9$ & 6.2 \\
\hline Average Bond Spreads & 6.7 & 5.9 \\
\hline \multicolumn{2}{l}{ Bond Spreads Std. Dev.(\%) } & $4.0 / 23.1$ \\
\hline \multicolumn{3}{l}{ Sources: Author's calculations and Bloomberg } \\
For domestic currency debt, data are from 2009M1 to 2011M5.
\end{tabular}

\subsection{Comparison with the Model of a Risk-neutral Creditor}

To understand the role of a creditor's risk aversion, we contrast moments of bond spreads to those under a conventional sovereign debt model with a risk-neutral creditor, as in Aguiar and Gopinath (2006) and Arellano (2008). As reported in Table 8, average bond spreads in the current model are higher and closer to the data than those in a model with a risk-neutral creditor in both pre- and postdefault periods. Moreover, the current model generates higher standard deviations of bond spreads than the model with a risk-neutral creditor. These are associated with high average bond spreads, since we assume no spreads when the sovereign is in autarky.

What drives a large difference in average bond spreads is the risk aversion of the creditor. Both

\footnotetext{
${ }^{27}$ Given the lack of spreads data on domestic currency bonds before 2009M1, we focus on moments of spreads in post-default periods.
} 
average bond spreads and the standard deviation in the current model are higher and closer to the data than those in a traditional sovereign debt model with a risk-neutral creditor. In a standard model with a risk-neutral creditor, bond spreads do not include any spread premia since bond prices are simply determined by default probability. On the contrary, in the current model with the riskaverse creditor, bond prices are determined by interaction between stochastic discount factors and expected payoff, as shown in equation (25) and (26). Risk premia, due to risk aversion of the creditor, are included in bond spreads and increase spreads close to the data.

Table 7: Statistics for Bond Spreads

\begin{tabular}{llll}
\hline & Data & Baseline & Model - Risk-neutral creditor \\
\hline Before Default & & \\
\hline Average Bond Spreads & 7.6 & 5.9 & 1.1 \\
\hline Bond Spreads Std. Dev.(\%) & 2.7 & 5.8 & 2.4 \\
\hline After Defaults/Restructurings & & \\
\hline Average Bond Spreads & $6.7 / 22.9$ & 6.2 & 0.8 \\
\hline Bond Spreads Std. Dev.(\%) & $4.0 / 23.1$ & 5.9 & 2.0 \\
\hline Sources: Author's computations and Bloomberg
\end{tabular}

\section{Model Implications}

In this section, we explore determinants of real exchange rate dynamics. Key parameters influencing real exchange rate dynamics include income processes, elasticity of substitution, and share of foreign currency debt. Hence, we first report the effects of income processes on default probability and real exchange rate moments. We then examine influence of share of foreign currency debt.

\subsection{Volatility of Income Processes and Real Exchange Rate Dynamics}

Table 8 reports key moment statistics under different values of the standard deviation of endowments $\sigma^{T}$ and $\sigma^{N}$, elasticity of substitution between tradable and non-tradable goods $\kappa$ and discount rate $\delta$, leaving other parameters at their benchmark values.

Lower discount rates yield both a higher default probability and a higher level of debt. When the sovereign is less patient and willing to increase current consumption, the soverign tends to accumulate 
more debt resulting in frequent defaults. Real exchange rate moments are similar to those in the baseline case.

When tradable and non-tradable goods are highly substitutable $(\kappa=2.5)$, the sovereign can smooth volatility of consumption of tradable goods by substituting with non-tradable goods. This results in a smaller change in marginal substitution of consumption, leading to a smaller change in the real exchange rate. Therefore, real exchange rate depreciation and volatility are smaller than those under the benchmark case.

Volatile income processes for both traded and non-traded goods result in higher default probability and lower level of debt. Due to an increase in volatility of income realization, the sovereign tends to default more frequently with a lower level of debt. Through positive correlation between the real exchange rate and spreads, volatile income processes for both traded and non-traded goods relate to high standard deviations of the real exchange rate in both pre-default and post-default periods.

Table 8: Model Statistics for Argentina (in quarterly frequency)

\begin{tabular}{lccccccccc} 
& Baseline & \multicolumn{1}{c}{$\delta$} & & $\kappa$ & & $\sigma^{T}$ & $\sigma^{N}$ \\
\hline & & 0.80 & 0.96 & 0.8 & 2.5 & 0.02 & 0.058 & 0.02 & 0.058 \\
\hline Default probability (\%) & 3.4 & 3.8 & 1.6 & 1.8 & 0.5 & 1.9 & 3.9 & 2.0 & 4.7 \\
\hline Before Default & & & & & & & & & \\
\hline Average Debt/GDP (\%) & 13.5 & 16.6 & 3.0 & 21.2 & 33.2 & 16.7 & 12.7 & 15.0 & 13.0 \\
\hline Average Real Exchange Rate & 0.98 & 0.98 & 1.02 & 0.98 & 0.99 & 0.98 & 0.98 & 0.98 & 0.97 \\
\hline Real Exchange Rate Std. Dev. (\%) & 9.4 & 9.3 & 8.8 & 5.8 & 1.9 & 7.6 & 9.9 & 8.1 & 10.3 \\
\hline After Default & & & & & & & & \\
\hline Average Debt/GDP (\%) & 11.7 & 14.4 & 3.1 & 19.1 & 32.1 & 15.1 & 11.1 & 13.3 & 11.3 \\
\hline Average Real Exchange Rate & 1.05 & 1.05 & 1.04 & 1.02 & 1.00 & 1.03 & 1.05 & 1.04 & 1.05 \\
\hline Real Exchange Rate Std. Dev (\%) & 9.5 & 9.5 & 8.6 & 5.9 & 1.9 & 7.6 & 9.8 & 8.1 & 10.3 \\
\hline
\end{tabular}

\subsection{Share of Foreign Currency Bonds and Real Exchange Rate}

Table 9 shows how default probability, average debt and real exchange rate moments change under different values of share of foreign currency debt $1-\alpha$ leaving other parameters at their benchmark values. Smaller share of foreign currency debt leads to lower default probability and lower average real 
exchange rate in post-default periods; if the sovereign issues more debt in domestic currency $(1-\alpha=$ 0.5), one-percentage real exchange rate depreciation does not increase much burden of payments in terms of local currency, reducing default probability. The smaller share of foreign currency debt also results in higher average debt. On the contrary, standard deviations of real exchange rate are similar to those under a large share of foreign currency debt.

Table 9: Model Statistics for Argentina (in quarterly frequency) Share of foreign currency debt

\begin{tabular}{lccc}
\hline & $1-\alpha=0.5$ & $1-\alpha=0.75$ & $1-\alpha=0.99$ \\
\hline Default probability (\%) & 3.05 & 3.2 & 3.4 \\
\hline Before Default & & & \\
\hline Average Debt/GDP ratio (\%) & 17.9 & 15.3 & 13.5 \\
\hline Average Real Exchange Rate & 0.965 & 0.973 & 0.98 \\
\hline Real Exchange Rate Std. Dev. (\%) & 9.8 & 9.7 & 9.4 \\
\hline After Default & & & 11.7 \\
\hline Average Debt/GDP ratio (\%) & 15.6 & 13.5 & 1.05 \\
\hline Average Real Exchange Rate & 1.037 & 1.04 & 9.5 \\
\hline Real Exchange Rate Std. Dev (\%) & 9.8 & 9.7 & \\
\hline
\end{tabular}

Source: Author's calculation

\section{Conclusion}

Emerging countries experience real exchange rate depreciations around default events. This paper attempts to explore this observed evidence within a dynamic stochastic general equilibrium model in which bond issuance in local and foreign currencies is explicitly embedded and the real exchange rate and default risk are determined endogenously. Our quantitative analysis using data of Argentina, replicates a link between real exchange rate depreciation and default probability before and after defaults.

In the model, before default, the sovereign, receiving a series of low tradable goods shocks, tends to accumulate more debt and faces real exchange rate depreciation. Since a majority of debt is denominated in foreign currency, this, in turn, increases the burden of payments in terms of local 
currency, increasing default probability and forcing the sovereign to default. Once the sovereign declares default, it suffers output costs due to default and loses access to the market. By defaulting, the sovereign prefers to have a higher consumption of traded goods indicating lower marginal utility of consumption, which leads to both a higher price of non-traded goods and a higher overall price level. Thus, the default ends up with a further depreciation of the real exchange rate. This mechanism drives the equilibrium depreciation of real exchange rate in the model, and it is a plausible explanation of the observed pattern in the data.

So far, we have analyzed the endogenous real exchange rate dynamics before and after the default in the framework, where income processes are exogenous and output cost is fixed. It will be possible to consider interactions between real exchange rate depreciation and output costs due to default as in Mendoza and Yue (2012). This might be a potential area future research could explore.

\section{References}

[1] Aghion, P., and Bacchetta, P., and A. Banerjee, 2004, "A Corporate Balance-sheet Approach to Currency Crises," Journal of Economic Theory, Vol. 119(1), pp.6-30.

[2] Aguiar, M., and G. Gopinath, 2006, "Defaultable Debt, Interest Rates and the Current Account," Journal of International Economics, Vol.69(1), pp.64-83.

[3] Aguiar, M., and G. Gopinath, 2007, "Emerging Market Business Cycle: The Cycle is the Trend," Journal of Political Economy, Vol.115(1), pp.69-102.

[4] Arellano, C., 2008, "Default Risk and Income Fluctuations in Emerging Economies," American Economic Review, Vol.98(3), pp.690-712.

[5] Arellano, C., and J. Heathcote, 2010, "Dollarization and Financial Integration," Journal of Economic Theory, Vol. 145(3), pp.944-973. .

[6] Asonuma, T., 2012, "Serial Default and Debt Renegotiation," forthcoming IMF Working Paper.

[7] Asonuma, T., and C. Trebesch, 2013, "Sovereign Debt Restructurings: Preemptive and PostDefault" manuscript, IMF. 
[8] Benigno, G., and C. Thoenissen, 2008, "Consumption and Real Exchange Rates with Incomplete Markets and Non-Traded Goods," Journal of International Money and Finance, Vol.27, pp.926948.

[9] Benjamin, D., and M. Wright, 2009, "Recovery Before Redemption? A Theory of Delays in Sovereign Debt Renegotiations," manuscript, University of Southhampton.

[10] Bi, R., 2008, ""Beneficial" Delays in Debt Restructuring Negotiations," IMF working paper No.WP/08/38, International Monetary Fund.

[11] Borensztein E., and U. Panizza, 2010, "Do Sovereign Defaults Hurt Exports?" Open Economic Review, Vol.21(3), pp.393-412.

[12] Borri, N., and A. Verdelhan, 2009, "Sovereign Risk Premia," manuscript, LUISS.

[13] Burger, J., and F. Warnock, 2006, "Local Currency Bond Market," IMF Staff Papers, Vol. 53, Special Issue.

[14] Bussiere, M., Fratzscher, M., and W. Koeniger, 2004, "Currency Mismatch, Uncertainty, and Debt Structure," ECB Working Paper No.0409.

[15] Chamon, M., and R. Hausmann, 2004, "Why Do Countries Borrow the Way They Borrow?" in B. Eichengreen and R. Hausmann eds., Other People's Money - Debt Denomination and Financial Instability in Emerging Market Economies, University of Chicago Press.

[16] Chari, V.V., Kehoe, P., and E. McGrattan, 2002, "Can Sticky Price Models Generate Relative and Persistent Real Exchange Rates?" Review of Economic Studies, Vol.69, pp.633-663.

[17] Coeurdacier, N., and P.O. Gourinchas, 2013, "When Bonds Matter: Home Bias in Goods and Assets" manuscript, SciencePo.

[18] Corsetti, G., and B. Mackowiak, 2004, "A Fiscal Perspective on Currency Crises and Original Sin," in B. Eichengreen, and R. Hausmann, eds., Other People's Money - Debt Denomination and Financial Instability in Emerging Market Economies, University of Chicago Press.

[19] Devereux, M., and A. Sutherland, 2009, "A Portfolio Model of Capital Flows to Emerging Markets," Journal of Development Economics, Vol.89, pp.181-193. 
[20] Dreher, A. and S. Walter, 2010, "Does the IMF help or hurt? The Effect of IMF Program on the Likelihood and Outcomes of Currency Crises," World Development, Vol. 38(1), 1-18.

[21] Eaton, J. and M. Gersovitz, 1981, "Debt with Potential Repudiation: Theoretical and Empirical Analysis," Review of Economic Studies, Vol.48, pp.289-309.

[22] Eichengreen, B., Hausmann, R., and U Panizza, 2004, "The Mystery of Original Shin" in B. Eichengreen and R. Hausmann (eds.), Debt Denomination and Financial Instability in Emerging Market Economies, Chicago, University of Chicago Press.

[23] Gelos, G., Sahay, R., and G. Sandleris, 2011, "Sovereign Borrowing in Developing Countries: What Determines Market Access?" Journal of International Economics, Vol.83(2), pp.243-254.

[24] Hussey, R., and G. Tauchen, 1991, "Quadrature-Based Methods for Obtaining Approximate Solutions to Nonlinear Asset Pricing Models," Econometrica, Vol.59(2), pp.371-396.

[25] International Monetary Fund, 2006, "Methodology for CGER Exchange Rate Assessments," Working Paper, November 2006.

[26] Jahjah, S., Wei, B., and V. Yue, 2012, "Exchange Rate Policy and Sovereign Bond Spreads in Developing Countries," forthcoming in Journal of Money, Credit and Banking.

[27] Jeanne, O., 2003, "Why Do Emerging Market Economies Borrow in Foreign Currency?" IMF Working Paper WP/03/177.

[28] Kohlscheen, E., 2009, "Sovereign Risk: Constitutions Rule," Oxford Economic Papers, Vol.62(1), pp.62-85.

[29] Lizarazo, S. V., 2013, "Default Risk and Risk Averse International Investors," Journal of International Economics, Vol. 89 (2), pp.317-330.

[30] Maeso-Fernandez, F., Osbat, C., and B. Schnatz, 2001, "Determinants of Euro Effective Exchange Rate: A BEER/PEER Approach," ECB Working Paper, No. 85.

[31] Mendoza. E., and V. Yue 2012, "A General Equilibrium Model of Sovereign Default and Business Cycles," Quarterly Journal of Economics, Vol.127(2), pp.889-946. 
[32] Neumeyer, P., and F. Perri, 2005, "Business Cycles in Emerging Economies: the Role of Interest Rates," Journal of Monetary Economics, Vol.52, pp.345-380.

[33] PRC Group, 2012, Composite Risk Rating.

[34] Strurzenegger, F., 2002, "Default Episodes in the 90s; Fact Book Preliminary Lessons," manuscript, Universidad Torcuato Di Tella.

[35] Strurzenegger, F., and J. Zettelmeyer, 2006, Debt Defaults and Lessons from a Decade of Crises, MIT Press.

[36] Sy, A.N.R., 2002, "Emerging Market Bond Spreads and Sovereign Risk Ratings: Reconciling Market Views and Economic Fundamentals," Emerging Market Review, Vol.3, pp.380-408.

[37] Tille, C., and E. Van Wincoop, 2010, "International Capital Flow," Journal of International Economics, Vol.80, pp.157-175.

[38] Walsh, C., 2003, Monetary Theorey and Policy, Cambridge, MA: MIT Press.

[39] Yue, V., 2010, "Sovereign Default and Debt Renegotiation," Journal of International Economics, Vol.80(2), pp.176-187.

\section{A Computation Algorithm}

The procedure to compute the stationary equilibrium distribution of the model is the following.

(i) First, we set grids on the space of asset holdings as $B=[-0.6, \ldots \ldots ., 0]$. The limits of the asset space are set to ensure that the limits do not bind in equilibrium.

(ii) Second, we set finite grids on the space of endowments of both the sovereign and the creditor. The limits of each endowment space are big enough to include large deviations from the average value of shocks. We approximate stochastic income processes given by equation (38) using a discrete Markov chain of equally-spaced grids. Moreover, we calculate the transition matrix based on the probability distribution $\mu\left(y_{t+1} \mid y_{t}\right)$.

(iii) Third, we set the initial value of the real exchange rate $\left(e_{0}=1\right.$, and $\left.e_{0}^{D}=1\right)$.

(iv) Fourth, we set the initial value for equilibrium bond price. We use the risk-free bond price $\left(q_{1}=\bar{q}=(1+r)^{-1}\right)$ for the baseline value for equilibrium bond price. 
(v) Fifth, given the baseline equilibrium bond price $\left(q_{0}^{H}=\bar{q}\right)$ and real exchange rate $\left(e_{0}=1\right)$, we solve for the country's and its creditor's optimization problems. This procedure finds the value function as well as default decisions. In order to solve the limit of the finite-horizon problem, we solve backwards. We start with the problem of last period. Then, we solve the last two-period problem. We keep iterating the process until we obtain the converged value function.

We first guess the value function $\left(V^{0}, V^{D, 0}\right)$ and iterate it using the Bellman equation to find the fixed value $\left(V^{*}, V^{D, *}\right)$, given the baseline bond price and real exchange rate. By iterating the Bellman function, we also derive the optimal asset policy function $\left(b^{\prime}\right)$. In addition, we obtain default choices, which require comparison of values of defaulting and non-defaulting choices. By contrasting these two values, we calculate a default set. Based on the derived default set, we also evaluate the default probability using a transition matrix.

(vi) Sixth, using a default set in step (v) and bond price equations (25) and (26), we compute the new bond price $\left(q_{1}^{H}\right.$ and $\left.q_{1}^{F}\right)$. Then, we iterate $(\mathrm{v})$ to have a fixed value of the equilibrium bond price.

(vii), Seventh, using the default set in step (v) and equation (12), (13), (21), (22) and (27), we

calculate the new real exchange rate $\left(e_{1}, e_{1}^{D}\right)$. Then we iterate step (v) and (vi) to have a fixed value of equilibrium real exchange rate.

\section{B Data and Empirical Analysis in Section 2}


Table A1: Details and Sources of Marcoeconomic Variables

\begin{tabular}{lll} 
Variable & Frequency & Source \\
\hline \hline Real exchange rate & Monthly & IMF IFS \\
Ratings & Monthly & S\&P, Moody's \\
GDP growth rate & Yearly & IMF WEO \\
Debt service-to-GDP & Yearly & IMF WEO \\
Institutional quality & Monthly & PRC \\
IMF program & Monthly & IMF \\
LIBOR 1-year & Monthly & LIBOR \\
GDP growth rate differential & Yearly & IMF WEO \\
Real interest rate differential & Yearly & IMF IFS \\
Net foreign asset-to-GDP & Yearly & IMF IFS \\
Real oil price shock & Yearly & IMF WEO \\
\hline \hline
\end{tabular}

We briefly explain how instruments used for regression analysis are appropriate. First, for the pre-default period, we use both US GDP deviation from the trend and the US Treasury bill rate as instruments for lagged real exchange rates. These variables, entered with a lag, are correlated with sovereigns' real exchange rates against the US dollar, but not with default probability of sovereigns. Moreover, in the first-stage regression, these variables are significant at 1 percent, and the specification fits the data well, shown by high $\mathrm{Adj}-R^{2}$ and small root mean square errors (MSE).

Table A2: 1st-stage Regression Results for the Pre-Default period

\begin{tabular}{lc} 
Dependent variable: Real Exchange rates, lagged & (A) Baseline. \\
\hline \hline Estimation & Least square \\
US GDP deviation from trend, lagged & $-19.67^{* * *}(4.55)$ \\
US Treasury rate, lagged & $0.23^{* * *}(0.01)$ \\
\hline \hline Samples & 106 \\
Adj- $R^{2}$ & 0.71 \\
Root MSE & 0.51 \\
\hline \hline Note: ${ }^{*},{ }^{* *},{ }^{* * *}$ denote significant at $10 \%, 5 \%$, and $1 \%$, respectively.
\end{tabular}

Next, for the post-default period, ratings of foreign countries and sovereigns' institutional quality 
are considered to be appropriate instruments for ratings, which are proxy for default choice / default probability. Sovereigns' ratings are correlated with ratings on foreign countries, since the method by how credit rating agencies assess other countries with similar economic size and macro framework influence sovereigns' ratings. In addition, institutional quality is one of the factors which credit rating agencies use to judge sovereigns' ratings. As the first-stage regression results clearly show, they are significant at 5 percent and 1 percent, respectively, and have high explanatory power (high $\operatorname{Adj}-R^{2}$ ).

Table A3: 1st-stage Regression Results for the Post-Default Period

\begin{tabular}{ll} 
Dependent variable: Ratings, lagged & (A) Baseline. \\
\hline \hline Estimation & Least square \\
Ratings on foreign countries, lagged & $-0.27^{* *}(0.12)$ \\
Institutional quality, lagged & $0.10^{* * *}(0.018)$ \\
\hline \hline Samples & 60 \\
Adj- $R^{2}$ & 0.75 \\
Root MSE & 2.08 \\
\hline \hline Note: ${ }^{*},{ }^{* *},{ }^{* *}$ denote significant at $10 \%, 5 \%$, and $1 \%$, respectively.
\end{tabular}

\section{Share of Foreign Currency Debt}


Table A4: Average and Variance of Shares of Foreign Currency Debt

\begin{tabular}{lcccc} 
& \multicolumn{2}{c}{ Before/after defaults/restructuring } & After defaults/restructuring \\
\hline \hline & from $t-5$ to $t+5$ & from $t$ to $t+5$ \\
& Average & Variance & Average & Variance \\
Argentina 2001-5 & $99 \%$ & $0 \%$ & $98 \%$ & $0 \%$ \\
Belize 2006-7 & $100 \%$ & $0 \%$ & $100 \%$ & $0 \%$ \\
Belize 2012-13 & $100 \%$ & $0 \%$ & $100 \%$ & $0 \%$ \\
Cote D'Ivoire & $100 \%$ & $0 \%$ & $100 \%$ & $0 \%$ \\
Dominican Rep. & $98 \%$ & $1 \%$ & $98 \%$ & $0 \%$ \\
Ecuador 1998-2000 & $100 \%$ & $0 \%$ & $100 \%$ & $0 \%$ \\
Ecuador 2008-9 & $100 \%$ & $0 \%$ & $100 \%$ & $0 \%$ \\
Grenada 2004-5 & $84 \%$ & $2 \%$ & $84 \%$ & $0 \%$ \\
Grenada 2013 & $74 \%$ & $0 \%$ & $74 \%$ & $0 \%$ \\
Iraq & $100 \%$ & $0 \%$ & $100 \%$ & $0 \%$ \\
Moldova & $100 \%$ & $0 \%$ & $100 \%$ & $0 \%$ \\
Pakistan & $100 \%$ & $0 \%$ & $100 \%$ & $0 \%$ \\
Russia & $100 \%$ & $0 \%$ & $100 \%$ & $0 \%$ \\
Seychelles & $100 \%$ & $0 \%$ & $0 \%$ & $0 \%$ \\
Ukraine 1998-9 & $100 \%$ & $0 \%$ & $0 \%$ & $0 \%$ \\
Uruguay & $100 \%$ & $1 \%$ & $0 \%$ & $0 \%$ \\
\hline
\end{tabular}

\section{Figures for Bond Prices}

The left panel of Figure A1 shows the bond price schedule with a different level of new debt issuance given initial debt of 0.3. Bond price is weakly decreasing with the level of new bond issuance, since it incorporates default probability, which is weakly increasing with respect to the level of new bond issuance. Next, the bond price schedule with the initial level of debt is presented in the right panel of Figure A1. At each level of debt, bond price is computed based on an optimal amount of bond issuance. This figure clearly shows that bond price is weakly decreasing with level of initial debt because expected default probability is higher for the high level of initial debt. 
Figure A1: Bond Prices

(A) Bond Price with Current Debt Fixed at 0.3 Bond price schedule with $b_{t}=-0.3$

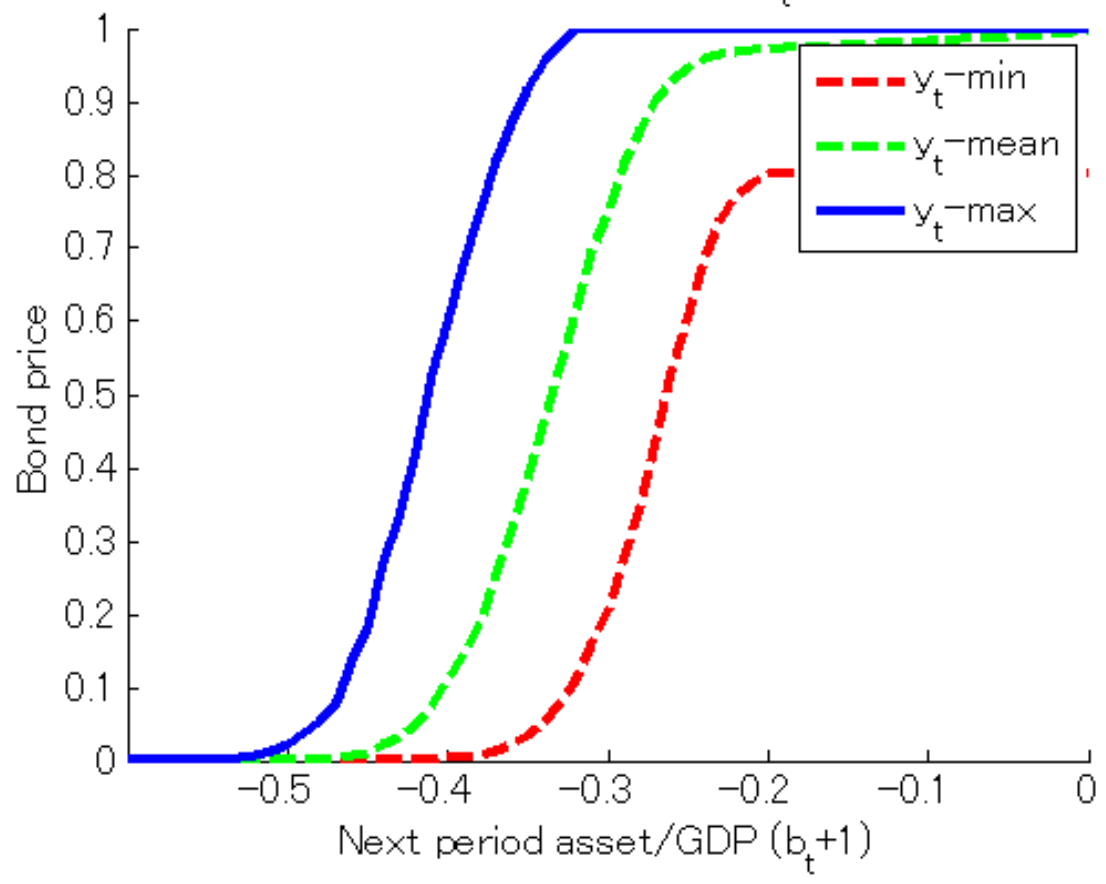

(B) Bond Price with Current Debt

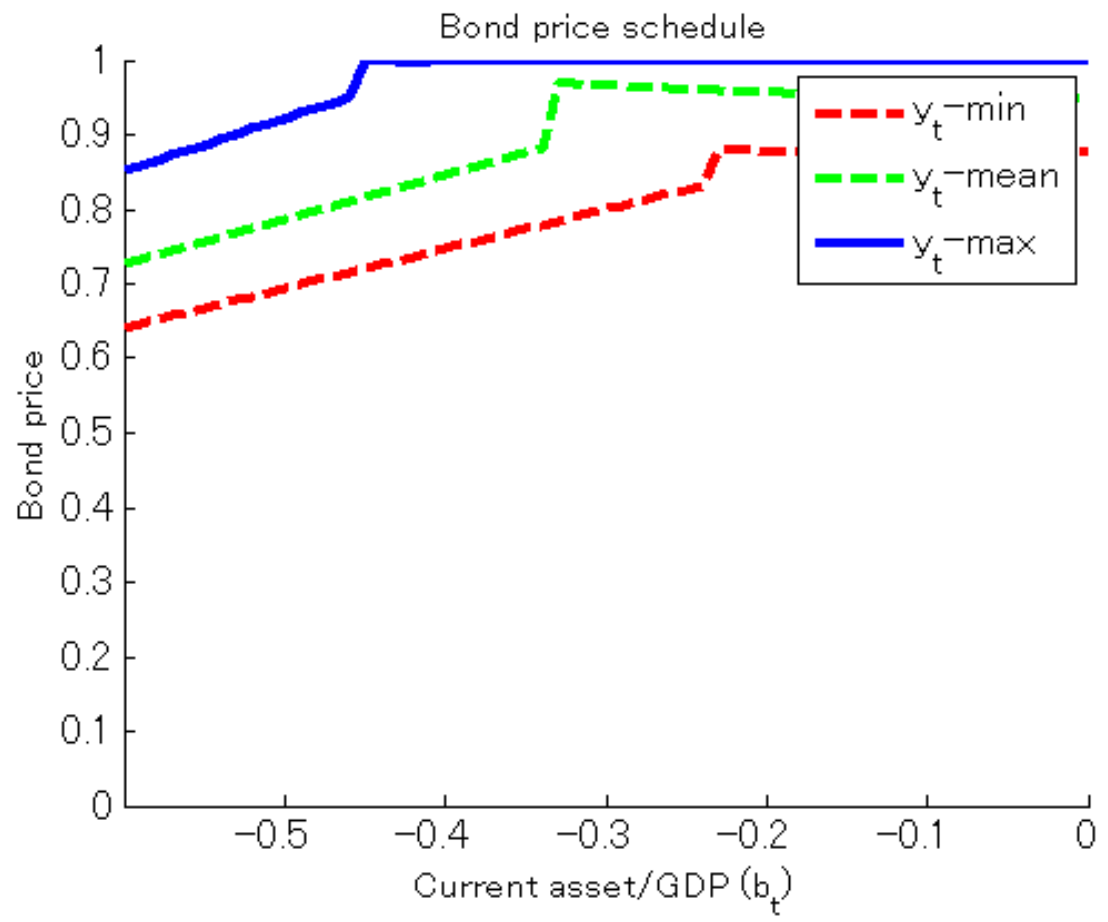

